\title{
An EARLINET early warning system for atmospheric aerosol aviation hazards
}

Nikolaos Papagiannopoulos ${ }^{1,2}$, Giuseppe D'Amico ${ }^{1}$, Anna Gialitaki ${ }^{3,4}$, Nicolae Ajtai ${ }^{5}$, Lucas Alados-Arboledas $^{6}$, Aldo Amodeo $^{1}$, Vassilis Amiridis ${ }^{3}$, Holger Baars ${ }^{7}$, Dimitris Balis ${ }^{4}$, Ioannis Binietoglou ${ }^{8}$, Adolfo Comerón ${ }^{2}$, Davide Dionisi $^{9}$, Alfredo Falconieri ${ }^{1}$, Patrick Fréville ${ }^{10}$, Anna Kampouri ${ }^{3,4}$, Ina Mattis ${ }^{11}$, Zoran Mijicí ${ }^{12}$, Francisco Molero ${ }^{13}$, Alex Papayannis ${ }^{14}$, Gelsomina Pappalardo ${ }^{1}$, Alejandro Rodríguez-Gómez ${ }^{2}$, Stavros Solomos $^{3}$, and Lucia Mona ${ }^{1}$

${ }^{1}$ Consiglio Nazionale delle Ricerche - Istituto di Metodologie per l'Analisi Ambientale (CNR-IMAA),

C. da S. Loja, Tito Scalo (PZ), Italy

${ }^{2}$ CommSensLab, Dept. of Signal Theory and Communications, Universitat Politècnica de Catalunya, Barcelona, Spain

${ }^{3}$ IAASARS, National Observatory of Athens, Athens, Greece

${ }^{4}$ Laboratory of Atmospheric Physics, Physics Department, Aristotle University of Thessaloniki, Thessaloniki, Greece

${ }^{5}$ Faculty of Environmental Science and Engineering, Babes-Bolyai University of Cluj Napoca, Cluj, Romania

${ }^{6}$ Department of Applied Physics, University of Granada, Granada, Spain

${ }^{7}$ Leibniz Institute for Tropospheric Research (TROPOS), Leipzig, Germany

${ }^{8}$ National Institute of R\&D for Optoelectronics (INOE), Magurele, Romania

${ }^{9}$ Consiglio Nazionale delle Ricerche - Istituto di Scienze Marine (CNR-ISMAR), Rome, Italy

${ }^{10}$ Observatoire de Physique du Globe (OPGC-LaMP), Clermont-Ferrand, France

${ }^{11}$ Deutscher Wetterdienst, Meteorologisches Observatorium Hohenpeißenberg, Hohenpeissenberg, Germany

${ }^{12}$ Institute of Physics Belgrade, University of Belgrade, Belgrade, Serbia

${ }^{13}$ Centro de Investigaciones Energéticas, Medioambientales y Tecnológicas, Department of Environment, Madrid, Spain

${ }^{14}$ Laser Remote Sensing Unit, Physics Department, National Technical University of Athens, Athens, Greece

Correspondence: Nikos Papagiannopoulos (nikolaos.papagiannopoulos@imaa.cnr.it)

Received: 24 February 2020 - Discussion started: 27 February 2020

Revised: 5 June 2020 - Accepted: 3 August 2020 - Published: 15 September 2020

\begin{abstract}
A stand-alone lidar-based method for detecting airborne hazards for aviation in near real time (NRT) is presented. A polarization lidar allows for the identification of irregular-shaped particles such as volcanic dust and desert dust. The Single Calculus Chain (SCC) of the European Aerosol Research Lidar Network (EARLINET) delivers high-resolution preprocessed data: the calibrated total attenuated backscatter and the calibrated volume linear depolarization ratio time series. From these calibrated lidar signals, the particle backscatter coefficient and the particle depolarization ratio can be derived in temporally high resolution and thus provide the basis of the NRT early warning system (EWS). In particular, an iterative method for the retrieval of the particle backscatter is implemented. This improved capability was designed as a pilot that will produce
\end{abstract}

alerts for imminent threats for aviation. The method is applied to data during two diverse aerosol scenarios: first, a record breaking desert dust intrusion in March 2018 over Finokalia, Greece, and, second, an intrusion of volcanic particles originating from Mount Etna, Italy, in June 2019 over Antikythera, Greece. Additionally, a devoted observational period including several EARLINET lidar systems demonstrates the network's preparedness to offer insight into natural hazards that affect the aviation sector. 


\section{Introduction}

During the aviation crisis related to the volcanic eruption of Eyjafjallajökull, Iceland, in 2010, the European Aerosol Research Lidar Network (EARLINET; Pappalardo et al., 2014) provided range-resolved information to the World Meteorological Organization (WMO) on a daily basis (reports available at: https://www.earlinet.org, last access: 31 October 2019). The reports communicated the altitude, time, and location of the volcanic clouds over Europe. Furthermore, the time-height evolution of the lidar returns was freely available in near real time (NRT) on the EARLINET website. The nonautomated, non-harmonized, and non-homogenized process and the lack of tailored products for natural hazards made the EARLINET data disregarded in the decisionmaking process.

The lessons learned from the Eyjafjallajökull crisis emphasized the vulnerability of air transportation to natural hazards (Bolic and Sivcev, 2011). Volcanic ash plumes, as well as desert dust outbreaks, present an imminent threat to aviation as they lead, among others, to poor visibility with considerable consequences to flight operations (Bolic and Sivcev, 2011; Middleton, 2017). Aircraft that do fly in volcanic/desert dust conditions can have a variety of damage from scouring of surfaces to engine failure (Eliasson et al., 2016). The aftermath of an encounter can be immediate, reducing flight safety; furthermore, it can financially affect the airlines due to higher maintenance costs and the replacement of mechanical equipment.

Furthermore, the Eyjafjallajökull eruption highlighted the gap in the availability of real-time measurements and monitoring information for airborne hazards. Specifically, the lack of height-resolved information, a key aspect in flight planning and mitigation strategies, became evident. In the frame of the Horizon 2020 research project EUNADICS-AV (European Natural Disaster Coordination and Information System for Aviation; https://www.eunadics.eu, last access: 31 October 2019) funded by the European Commission, different organizations worked together in a consortium to provide relevant data during situations when aviation is affected by airborne hazards (e.g., volcanic ash, desert dust, biomass burning, radionuclide). Crucial for the overall success of the project and the early warning system (EWS) design were the review of the available observations and the collection of specific requirements from the different stakeholders that once more pointed out the importance of height-resolved information.

A polarization lidar is an important tool to characterize the different aerosols. This system permits the discrimination of light-depolarizing coarse-mode particles such as volcanic and desert dust and fine-mode particles such as smoke particles and anthropogenic pollution (e.g., Tesche et al., 2011; Mamouri and Ansmann, 2017). Further, the lidar setup allows for the retrieval of coarse-mode and fine-mode backscatter coefficients for wavelengths of 532 and $1064 \mathrm{~nm}$ (e.g., Tesche et al., 2009). When synergistically used with a photometer, it is possible to retrieve their mass concentration profile (e.g., Ansmann et al., 2012; Lopatin et al., 2013; Chaikovsky et al., 2016).

During the last years, EARLINET has strongly increased its observing capacity with the addition of new stations and a system upgrade, namely, the installation of depolarization channels. In addition, the further development of the Single Calculus Chain (SCC) (D'Amico et al., 2015, 2016; Mattis et al., 2016) under the ACTRIS (Aerosols, Clouds and Trace gases Research InfraStructure Network) umbrella eliminated the inconsistencies in the retrieval procedures and in the signal error calculation, automated the data evaluation, and now allows for NRT data processing and the generation of tailored products network-wide. EARLINET has already demonstrated the network's NRT capabilities, as well as assisted modeling studies in NRT evaluation and assimilation (Wang et al., 2014; Sicard et al., 2015). As a consequence, EARLINET is prepared to provide prompt, height-resolved information and tailored products that were greatly missed during the 2010 aviation crisis. Therefore, a methodology for an early warning system based solely on EARLINET data is developed.

In Sect. 2, we present the EARLINET remote sensing network and the data that we used in this study. In Sect. 3, we introduce the methodology of the EARLINET-based EWS. In Sect. 4, we present the results obtained by applying the methodology to real measurements and the lessons learned from a multi-station EARLINET observational period. Finally, in Sect. 5, we give our conclusions and indicate directions for future work.

\section{EARLINET}

The European Aerosol Research Lidar Network (EARLINET; Pappalardo et al., 2014) was established in 2000, provides aerosol profiling data on a continental scale, and is now part of the Aerosols, Clouds, and Trace gases Research InfraStructure (ACTRIS; https://www.actris.eu, last access: 31 October 2019). Nowadays, more than 30 stations are active and perform measurements according to the network's schedule (one daytime and two nighttime measurements per week). Figure 1 illustrates the network's geographic extent and the location of the active EARLINET stations (green squares) and the joining EARLINET stations (yellow squares), together with the non-active site of Finokalia (red square), for which lidar data are used in this study. Further measurements are devoted to special events, such as volcanic eruptions, forest fires, and desert dust outbreaks (e.g., Mona et al., 2012; Pappalardo et al., 2013; Ortiz-Amezcua et al., 2017; Granados-Muñoz et al., 2016). The majority of the EARLINET stations operate multi-wavelength Raman lidars that combine a set of elastic and nitrogen inelastic channels and are equipped with depolarization channels. This li- 


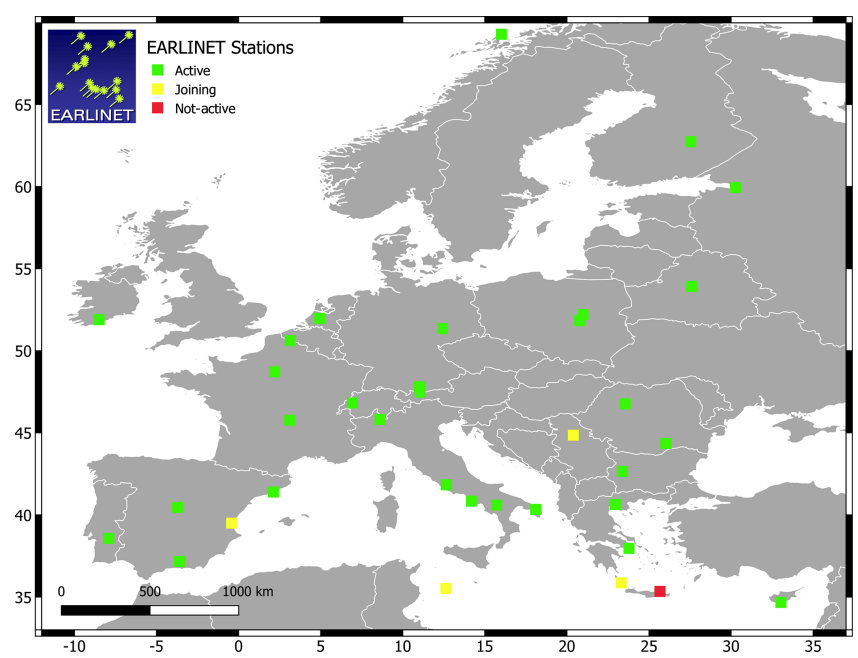

Figure 1. The EARLINET network in Europe. The green squares indicate the active stations, the yellow squares indicate the joining stations, and the red square indicates the non-active Finokalia, Greece, station.

dar configuration allows for the retrieval of intensive aerosol profiles, such as the particle lidar ratio, particle Ångström exponent, and particle depolarization ratio. These variables are shown to vary with the aerosol type and location, and, consequently, EARLINET stations are able to characterize the aerosol load (Müller et al., 2007). Accordingly, EARLINET has established tools for automatic aerosol characterization (Nicolae et al., 2018; Papagiannopoulos et al., 2018).

To ensure a homogeneous, traceable, and qualitycontrolled analysis of raw lidar data across the network, a centralized and fully automated analysis tool, called the Single Calculus Chain (SCC), has been developed within EARLINET (D'Amico et al., 2015, 2016; Mattis et al., 2016). Raw lidar data are first submitted to the central SCC server by each EARLINET station, and several lidar products are generated automatically. In particular, low-resolution (in both time and space) uncalibrated preprocessed products provided by the SCC EARLINET Lidar Pre-Processor (ELPP) module (D'Amico et al., 2016) and aerosol optical properties vertical profiles provided by the SCC EARLINET Lidar Data Analyzer (ELDA) module (Mattis et al., 2016) are made available. Recently a new version of the SCC has been released providing also standardized high-resolution preprocessed lidar products. These new products include the calibrated attenuated backscatter coefficient and volume linear depolarization ratio time series at instrumental time and space resolution. Particular attention has been paid to the calibration of the high-resolution products; an automatic and fully traceable calibration procedure using the low-resolution SCCretrieved particle backscatter and extinction coefficients has been designed and implemented in the SCC framework.

The cloud screening module is responsible for cloud identification in uncalibrated lidar signals and especially with low clouds since such clouds do not permit the aerosol optical property retrieval by ELDA. Note that the cloud removal is also essential in our EWS methodology. The input of the algorithm is the high-resolution preprocessed signals produced by the SCC HiRELPP (High-Resolution EARLINET Pre-Processor) module. The current cloud screening detects clouds as bins with irregularly high values in signal and edge strength (Nixon and Aguado, 2019; Tramutoli, 1998). The algorithm works well with uncalibrated signals recorded by multiple lidar systems across EARLINET. However, the false detection of aerosol-laden bins as cloud can occur, especially in cases where there is high contrast between an aerosol layer and the rest of the atmosphere. For this reason, the development of a cloud screening module based on calibrated lidar signals and quantitative criteria is foreseen.

The calibrated high-resolution data along with the cloud screening output are essential for the proposed methodology and are used in the EWS. The methodology to derive the particle high-resolution data that are described in Sect. 3 is first cloud cleared and second based on $5 \mathrm{~min}$ and $30 \mathrm{~m}$ averaged profiles in order to increase the signal-to-noise ratio.

\subsection{The sites of Finokalia and Antikythera, Greece}

The EARLINET component of NOA (National Observatory of Athens) for the period of April 2017 until May 2018 was deployed through the NOA lidar system on the north coast of Crete. The Finokalia Atmospheric Observatory $\left(35.34^{\circ} \mathrm{N}\right.$, $25.67^{\circ} \mathrm{E}$ ) is a research infrastructure with activities covering in situ aerosol characterization, 3-D aerosol distribution, and gas precursors. Since June 2018, the system has been located on the island of Antikythera, where a suite of remote sensing sensors are installed in order to study the properties of natural aerosol particles (e.g., sea salt, dust, volcanic ash) in Mediterranean background conditions. The islands of Crete and Antikythera are very often affected by windblown dust originating from the Sahara due to their proximity to the African coastline, and this can be along the traveled path of volcanic dust and sulfate aerosols from the Italian active volcanoes (e.g., Hughes et al., 2016).

The NOA lidar system Polly XT (e.g., Engelmann et al., 2016) operates in the frame of EARLINET and under the umbrella of ACTRIS. The system is equipped with three elastic channels at 355,532 , and $1064 \mathrm{~nm}$, two vibration-rotation Raman channels at 387 and $607 \mathrm{~nm}$, two linear depolarization channels at 355 and $532 \mathrm{~nm}$, and one water vapor channel at $407 \mathrm{~nm}$. Depending on the atmospheric conditions, the combined use of its near-range and far-range telescopes provides reliable vertical profiles of aerosol optical properties from $0.2-0.4 \mathrm{~km}$ to almost $16 \mathrm{~km}$ in height.

\subsection{Additional data}

For the detection of the desert dust plume, satellite imagery from the Spinning Enhanced Visible Infrared Imager (SE- 
VIRI) is used. SEVIRI is a line-by-line scanning radiometer on board the Meteosat Second Generation (MSG) geostationary satellite. It provides data in 12 spectral bands every 15 min for the full Earth disk area. The spatial resolution is around $3 \mathrm{~km}$ at the nadir, which is different from the highresolution visible (HRV) band $(1 \mathrm{~km})$. In this study, we used a largely accepted multi-temporal scheme of satellite data analysis (Tramutoli, 2007) to detect the dust plume over the Mediterranean basin. In particular, we used the eRST $\mathrm{DUST}_{\mathrm{S}}$ (enhanced robust satellite technique for dust detection) algorithm (Marchese et al., 2017), which combines an index analyzing the visible radiance (at around $0.6 \mu \mathrm{m}$ ) to another one based on the brightness temperature difference (BTD) of the signal measured by the SEVIRI spectral channels centered at 10.8 and $12 \mu \mathrm{m}$ wavelengths.

For the detection of the volcanic dust, we use the Lagrangian transport model FLEXPART (FLEXible PARTicle dispersion model; Brioude et al., 2013; Stohl et al., 2005) in a forward mode to simulate the dispersion of volcanic emissions from Mount Etna, Italy. Dispersion simulations are driven by hourly meteorological fields from the Weather Research and Forecasting model (WRF; Skamarock et al., 2008) at $36 \mathrm{~km} \times 36 \mathrm{~km}$ horizontal resolution. The initial and boundary conditions for the off-line coupled WRFFLEXPART runs are taken from the National Center for Environmental Prediction (NCEP) final analysis (FNL) dataset at a $1^{\circ} \times 1^{\circ}$ resolution at 6 -hourly intervals. The sea surface temperature (SST) is taken from the NCEP $0.5^{\circ} \times 0.5^{\circ}$ analysis. The simulated case study did not include an eruptive stage; therefore, the initial injection height is set from the crater level ( $3.3 \mathrm{~km}$ at sea level, a.s.l.) up to $4 \mathrm{~km}$ a.s.l. A total of 10000 tracer particles are released for this simulation. Dry and wet deposition processes are also enabled in these runs. Saharan dust transport is also described in WRF with the Air Force Weather Agency (AFWA) scheme (Jones et al., 2012).

\section{Methodology}

\subsection{Retrieval of the particle parameters in temporally high resolution}

The delivery of an alert using EARLINET data is based on a two-step approach. In the first step, the high-resolution calibrated data are used to estimate the particle backscatter coefficient and the particle linear depolarization ratio. In order to retrieve the particle backscatter coefficient, an iterative methodology is adapted. The methodology, described in Di Girolamo et al. (1999), is able to retrieve a particle backscatter coefficient with an overall error of no more than $50 \%$. Prior to that, the cloud contaminated pixels are removed from the data using the cloud screening algorithm developed for the SCC (see Sect. 2).

The method is similar to that of Mattis et al. (2016) in which SCC is employed to derive optical products from elas- tic backscatter signals. For an ever-available NRT and automated aerosol retrieval, we use channels for elastic backscattering, including depolarization, since Raman observations during daytime have been hitherto challenging.

The calibrated attenuated backscatter coefficient provided by the SCC can be written as

$\beta_{\text {att }}(\lambda, r)=\left[\beta_{\text {molec. }}(\lambda, r)+\beta_{\text {par }}(\lambda, r)\right] T_{\text {molec. }}^{2}(\lambda, r) T_{\text {par }}^{2}(\lambda, r)$,

where $\beta_{\text {par }}(\lambda, r)$ and $\beta_{\text {molec. }}(\lambda, r)$ are, respectively, the backscatter coefficient for particles (par) and molecules (molec.); $T_{\text {par }}^{2}(\lambda, r)$ and $T_{\text {molec. }}^{2}(\lambda, r)$ represent the two-way attenuation to and from range $r$ due to, respectively, particles and molecules at wavelength $\lambda$. The latter can be expressed as

$T_{\text {par/molec. }}^{-2}(\lambda, r)=\exp \left[-2 \int_{0}^{R} \alpha_{\text {par/molec. }}^{-1}(\lambda, r) \mathrm{d} r\right]$,

where $\alpha_{\text {par }}(\lambda, r)$ and $\alpha_{\text {molec. }}(\lambda, r)$ are the particle and molecular extinction coefficients, respectively. The term $\lambda$ is omitted from the subsequent expressions as the analysis explicitly focuses on $532 \mathrm{~nm}$. The terms $\alpha_{\text {molec. }}(r)$ and $\beta_{\text {molec. }}(r)$ can be estimated from temperature and pressure profiles.

In an initial step, the attenuation in the atmosphere is neglected, $\alpha_{\mathrm{par}}^{(0)}(r)=0 \mathrm{~m}^{-1} \Rightarrow T_{\mathrm{par}}^{(0)^{2}}(r)=1$, which reduces Eq. (1) to

$\beta_{\text {par }}^{(1)}(r)=\beta_{\text {molec. }}(r)\left[\frac{\beta_{\text {att }}(r)}{\beta_{\text {molec. }}(r) T_{\text {molec. }}^{2}(r)}-1\right]$.

The particle extinction coefficient is estimated by multiplying $\beta_{\mathrm{par}}^{(1)}(r)$ with a constant lidar ratio, $S_{\mathrm{par}}$. Using the particle extinction coefficient in Eq. (1) we derive a new backscatter coefficient given by

$\beta_{\text {par }}^{(2)}(r)=\beta_{\text {molec. }}(r)\left[\frac{\beta_{\text {att }}(r)}{\beta_{\text {molec. }}(r) T_{\text {molec. }}^{2}(r) T_{\text {par }}^{(1)^{2}}(r)}-1\right]$.

Baars et al. (2017) developed a method to derive atmospheric parameters in temporally high resolution, and they refer to the product of Eq. (4) as the quasi-particle backscatter coefficient, which serves as the best estimate for the particle backscatter coefficient. However, here the particle backscatter,

$\beta_{\mathrm{par}}^{(i)}(r)=\beta_{\text {molec. }}(r)\left[\frac{\beta_{\text {att }}(r)}{\beta_{\text {molec. }}(r) T_{\text {molec. }}^{2}(r) T_{\text {par }}^{(i-1)^{2}}(r)}-1\right]$,

is calculated in the $i$ th iteration step from the calibrated attenuated backscatter coefficient. The procedure is successfully terminated if the absolute difference between the backscatter coefficient of two subsequent profiles is smaller than a fixed threshold. The absolute difference, $\Delta_{\beta}$, is defined as

$\Delta \beta^{(i)}=\left|\int \beta_{\mathrm{par}}^{(i)} \mathrm{d} r-\int \beta_{\mathrm{par}}^{(i-1)} \mathrm{d} r\right|$. 
We found that fewer than 10 steps are required for a difference of $1 \%$ for the cases examined herein.

The particle depolarization ratio at $532 \mathrm{~nm}$ can be defined as (Baars et al., 2017)

$\delta_{\text {par }}=\left[\delta_{\mathrm{vol}}(r)+1\right] \times\left(\frac{\beta_{\text {molec. }}(r)\left[\delta_{\text {molec. }}-\delta_{\mathrm{vol}}(r)\right]}{\beta_{\text {par }}(r)\left[1+\delta_{\text {molec. }}\right]}\right)^{-1}-1$,

where $\delta_{\text {molec. }}$ is the molecular depolarization ratio and is calculated theoretically (Behrendt and Nakamura, 2002). The term $\delta_{\mathrm{vol}}(r)$ denotes the volume depolarization ratio, and it is the output of SCC.

The input lidar ratio value used in the retrieval could significantly affect the results. Papagiannopoulos et al. (2018) used $48 \pm 13 \mathrm{sr}$ for fresh volcanic particles and $55 \pm 7 \mathrm{sr}$ for desert dust particles observed over EARLINET sites in their aerosol classification, which illustrates the variability of this intensive parameter. The uncertainty induced due to the assumption of the lidar ratio can easily exceed $20 \%$ (Sasano et al., 1985) and presents an important source that affects the retrieval. In this study, $S_{\mathrm{par}}=50 \mathrm{sr}$ is chosen for the backscatter coefficient retrieval as it is a good compromise for many EARLINET sites and different aerosol conditions (Papayannis et al., 2008; Müller et al., 2007; Mona et al., 2014; Papagiannopoulos et al., 2016). Figure 2 shows a desert dust layer around $3 \mathrm{~km}$ over the Potenza EARLINET station on 4 April 2016, 18:47-22:15 UTC. The backscatter coefficient at $532 \mathrm{~nm}$ retrieved for 30,50 , and $70 \mathrm{sr}$ along with the backscatter coefficient from the Raman method is shown (Fig. 2a). The three curves almost coincide in the upper part (relative difference is around 5\%) and deviate from one another by less than $35 \%$ in the lower portion of the profile where local aerosol is mixed with dust particles.

The performance of the iterative method for $S_{\mathrm{par}}=50 \mathrm{sr}$ can be assessed in Fig. 2b. The overall agreement is very good with the relative difference being around $4 \%$; however, the iterative method underestimates almost everywhere the Raman method due to the assumption of $S_{\mathrm{par}}=50 \mathrm{sr}$ instead of the measured $43 \pm 7 \mathrm{sr}$. Figure $2 \mathrm{c}$ highlights the effect when the directly measured lidar ratio is plotted against the fixed lidar ratio. Evidently, the curves agree fairly well for the aerosol layer (e.g., desert dust) in the free troposphere and deviate from the layer below (i.e., values over $50 \mathrm{sr}$ ). As discussed above, the inference of the lidar ratio is an important factor, yet a lidar ratio value valid for a common volcanic dust and desert dust layer will provide a robust solution for this approach.

\subsection{Aviation alert delivery}

In the second step, the location and the intensity of the volcanic dust and desert dust event are identified. Mona and Marenco (2016) reported that particle depolarization ratio values were around $35 \%$ for freshly emitted particles from various volcanoes and that the values decrease with time. Similarly, pure Saharan dust particles are supposed
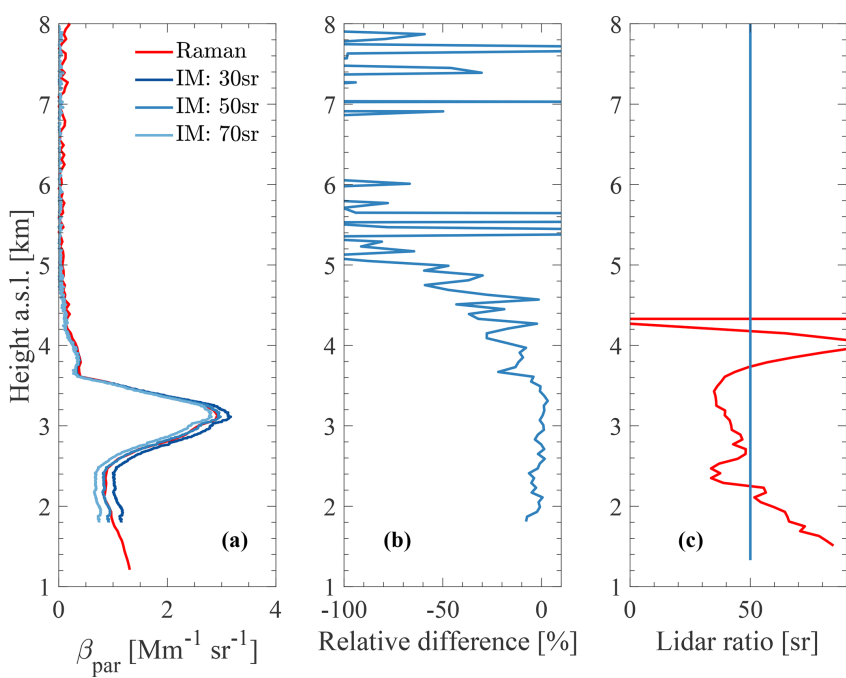

Figure 2. (a) The $532 \mathrm{~nm}$ backscatter coefficient retrieved with the iterative method (IM) for 30, 50, and $70 \mathrm{sr}$ along with the backscatter coefficient determined with the Raman method (standard SCC product) measured at Potenza (760 m a.s.1.), Italy, on 4 April 2016, 18:47-22:15 UTC. The lidar system of Potenza has a full overlap at around $1.15 \mathrm{~km}$ a.s.l. for $532 \mathrm{~nm}$ (Madonna et al., 2018). (b) The relative difference between the iterative method (IM: $50 \mathrm{sr}$ ) and the Raman method backscatter coefficient. (c) The lidar ratio profile measured with the Raman method and the fixed lidar ratio used for the iterative method.

to have a slightly smaller particle depolarization ratio of $31 \%$ (Freudenthaler et al., 2009). Since nonspherical particles such as volcanic and desert dust particles yield high particle depolarization ratio values, the one-step polarizationlidar photometer networking (POLIPHON) method is used (e.g., Ansmann et al., 2012).

The particle depolarization ratio is used to separate the nonspherical particles contribution to the particle backscatter coefficient. Mamouri and Ansmann (2014) describe in detail the retrieval process; however, here we treat volcanic dust and desert dust inextricably. The volcanic dust and desert dust backscatter coefficient can be expressed by

$\beta_{\mathrm{c}}=\beta_{\mathrm{par}} \frac{\left(\delta_{\mathrm{par}}-\delta_{\mathrm{nc}}\right)\left(1+\delta_{\mathrm{c}}\right)}{\left(\delta_{\mathrm{c}}-\delta_{\mathrm{nc}}\right)\left(1+\delta_{\mathrm{par}}\right)}$,

where the coarse (c) and non-coarse (nc) depolarization ratios are set to $\delta_{\mathrm{c}}=0.31$ and $\delta_{\mathrm{nc}}=0.05$, respectively. For values $\delta_{\mathrm{par}}<\delta_{\mathrm{nc}}$, we need to set $\beta_{\mathrm{nc}}=\beta_{\mathrm{par}}$. Similarly, when $\delta_{\text {par }}>\delta_{\mathrm{c}}$, we set $\beta_{\mathrm{c}}=\beta_{\mathrm{par}}$.

Until the aviation crisis in 2010, planes were advised to avoid the volcanic plumes regardless of the aerosol concentration (Guffanti et al., 2010). Recently, the International Civil Aviation Organization (ICAO, 2014) established three ash concentration thresholds which play a key role in the decision-making process. Aircraft are allowed to fly below $0.2 \mathrm{mg} \mathrm{m}^{-3}$, whereas they are forbidden to fly over 2 and $4 \mathrm{mg} \mathrm{m}^{-3}$ (depending on the aircraft's resilience). 


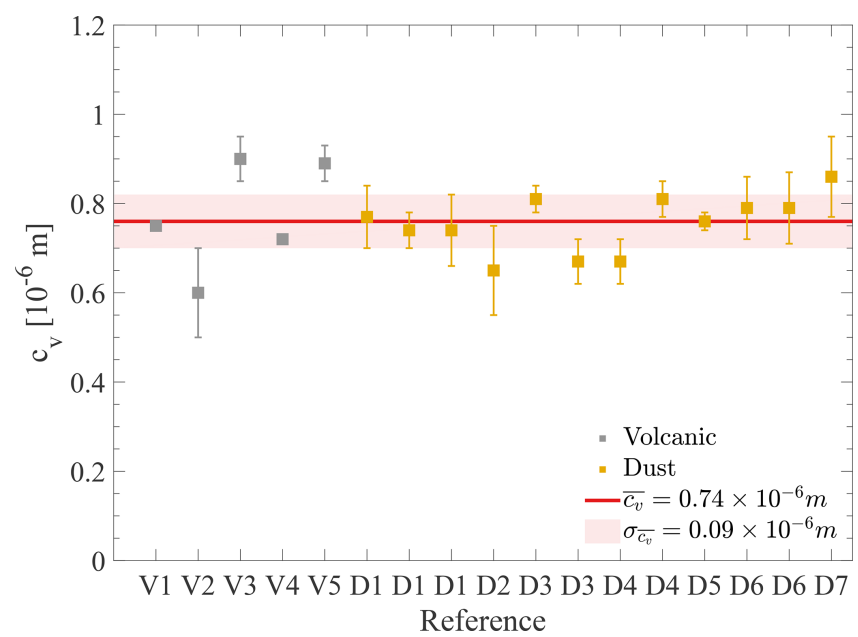

Figure 3. The scatter plot indicates the mean and the standard deviation of the conversion factor, $c_{\mathrm{V}}$, for the different literature references. The plot is color coded with respect to "Volcanic" (gray) and "Dust" (orange) observations. The red line highlights the overall mean conversion factor and the reddish-pink rectangle shows the standard deviation - i.e., $(0.76 \pm 0.06) \times 10^{-6} \mathrm{~m}$.

The methodology proposed by Ansmann et al. (2012) for the estimation of aerosol mass concentration profiles employs data from a single-wavelength polarization lidar. The methodology retrieves mass concentration profiles with an uncertainty of $20 \%-30 \%$, and it has proven to be robust and applicable to very different scenarios (e.g., Mamali et al., 2018; Córdoba-Jabonero et al., 2018) that need one wavelength and can be applied to cloudy skies. We chose to convert the three ash concentration thresholds into particle backscatter coefficient. The threshold values for the particle backscatter coefficient, $\beta_{\mathrm{th}}$, are estimated as

$\beta_{\mathrm{th}}=M \frac{1}{\rho c_{\mathrm{V}} S}$,

where $M$ is the mass concentration given by ICAO, $\rho$ the volcanic and desert dust bulk density, $c_{\mathrm{V}}$ the mass-to-extinction conversion factor, and $S$ the volcanic and desert dust lidar ratio. All the terms have to be assumed constant, and they are selected from the literature. The above concentration thresholds (e.g., 0.2, 2, $4 \mathrm{mg} \mathrm{m}^{-3}$ ) are used for the term $M$. For the $\rho$, we used the value $2.6 \mathrm{~g} \mathrm{~cm}^{-3}$ that corresponds to a commonly used value for volcanic and desert dust applications (e.g., Gasteiger et al., 2011; Ansmann et al., 2012; Binietoglou et al., 2015; Mamali et al., 2018). The term $S$ is chosen to be $50 \mathrm{sr}$ as a good compromise for fresh volcanic particles (e.g., Ansmann et al., 2011) and Saharan dust (e.g., Wiegner et al., 2012).

The term $c_{\mathrm{v}}$ can be estimated using Aerosol Robotic Network (AERONET) observations as being the ratio of the coarse column volume concentration, $v_{\mathrm{c}}$, to the coarse mode aerosol optical thickness, $\tau_{\mathrm{c}}$. More information on the different retrievals and AERONET data processing can be found
Table 1. The code used in Fig. 3 and the respective reference.

\begin{tabular}{ll}
\hline Code & Reference \\
\hline V1 & Ansmann et al. (2010) \\
V2 & Ansmann et al. (2011) \\
V3 & Ansmann et al. (2012) \\
V4 & Devenish et al. (2012) \\
V5 & Sicard et al. (2012) \\
D1 & Ansmann et al. (2012) \\
D2 & Binietoglou (2014) \\
D3 & Córdoba-Jabonero et al. (2018) \\
D4 & Mamali et al. (2018) \\
D5 & Mamouri and Ansmann (2014) \\
D6 & Mamouri and Ansmann (2017) \\
D7 & Ansmann et al. (2019) \\
\hline
\end{tabular}

in Ansmann et al. (2012), Mamouri and Ansmann (2017), and Ansmann et al. (2019). However, for an EWS and daynight availability, we have to select a constant value for volcanic dust and desert dust. Figure 3 shows an overview of AERONET-based $c_{\mathrm{V}}$ values. To interpret the horizontal axis of the figure, one should also look at Table 1. The figure is separated into volcanic (gray points) and desert (orange points) dust and depicts the range of the observed values; furthermore, the plot shows the mean and standard deviation for the overall average of the conversion factors. It is evident from Fig. 3 that for both volcanic and desert dust the values accumulate between 0.6 and $0.9 \times 10^{-6} \mathrm{~m}$ with a mean of $(0.76 \pm 0.06) \times 10^{-6} \mathrm{~m}$. It is worth noting that although most of the conversion factors were estimated using carefully selected AERONET observations, Mamouri and Ansmann (2017) and Ansmann et al. (2019) use a climatology to derive the conversion factor.

The conversion factor for the coarse particles (i.e., volcanic and desert dust) varies strongly with the distance from the source and, in the case of volcanic eruptions, with the eruption type. Ansmann et al. (2012) highlight that, when particles larger than $15 \mu \mathrm{m}$ (i.e., the higher limit of the assumed particles radii for the AERONET data analysis scheme) are present, the mass concentration may be underestimated by more than $100 \%$. The conversion factor in the case of dense and coarser plumes should be much higher and, consequently, will have an adverse impact on our EWS approach. For instance, Pisani et al. (2012) used a conversion factor of $0.6 \times 10^{-5} \mathrm{~m}$ for a freshly erupted volcanic plume near Mount Etna in Italy. A similar increase, although less pronounced, in the conversion factor can be observed in Mamouri and Ansmann (2017) and Ansmann et al. (2019), in which the authors retrieve a dust coarse-mode conversion factor (i.e., the values reported in Fig. 3). It is believed that particles bigger than $10 \mu \mathrm{m}$ usually fall quickly to the ground, whereas smaller particles can travel over long distances (Goudie and Middleton, 2006; Wilson et al., 2012). Conversely, van der Does et al. (2016) and Ryder et al. (2018) 


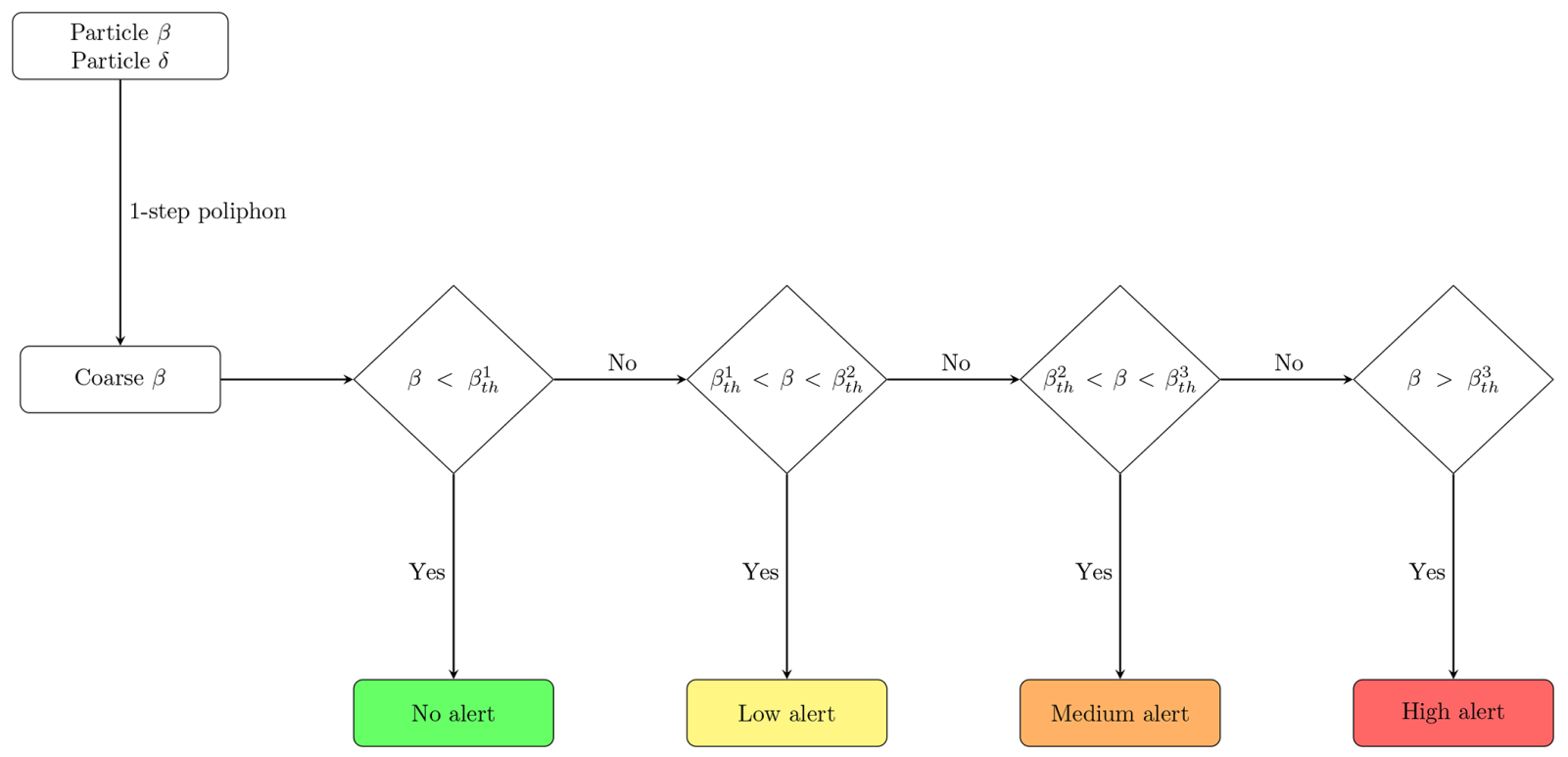

Figure 4. The EARLINET alert delivery scheme for aviation. The particle backscatter coefficient and depolarization ratio are used to estimate the coarse backscatter coefficient (one-step POLIPHON method). Three levels are considered that correspond to "Low alert" for particle concentrations higher than $0.2 \mathrm{mg} \mathrm{m}^{-3}$ and lower than $2 \mathrm{mg} \mathrm{m}^{-3}$, "Medium alert" for concentrations higher than $2 \mathrm{mg} \mathrm{m}^{-3}$ and lower than $4 \mathrm{mg} \mathrm{m}^{-3}$, and "High alert" for mass concentrations higher than $4 \mathrm{mg} \mathrm{m}^{-3}$. The three backscatter coefficient thresholds are $\beta_{\text {th }}^{1}=1.7 \times$ $10^{-6} \mathrm{~m}^{-1} \mathrm{sr}^{-1}, \beta_{\mathrm{th}}^{2}=1.7 \times 10^{-5} \mathrm{~m}^{-1} \mathrm{sr}^{-1}$, and $\beta_{\mathrm{th}}^{3}=3.4 \times 10^{-5} \mathrm{~m}^{-1} \mathrm{sr}^{-1}$.

have illustrated that the desert dust size far away from its source is much coarser than previously suggested, and this has been incorporated into climate models. In light of the above, we chose as the conversion factor in our approach the maximum retrieved value, which is $0.9 \times 10^{-6} \mathrm{~m}$ (Ansmann et al., 2012). Hence, the thresholds for the particle backscatter coefficient become $1.7 \times 10^{-6}$ (for $0.2 \mathrm{mg} \mathrm{m}^{-3}$ ), $1.7 \times 10^{-5}$ (for $2 \mathrm{mg} \mathrm{m}^{-3}$ ), and $3.4 \times 10^{-5} \mathrm{~m}^{-1} \mathrm{sr}^{-1}$ (for $4 \mathrm{mg} \mathrm{m}^{-3}$ ). Given also that the EARLINET stations are far from the active European volcanoes (i.e., Mount Etna and the Icelandic volcanoes), we consider that the selected AERONET-derived conversion factor holds for most of the situations.

Figure 4 illustrates the decision flowchart for the aviation alert delivery in which three alert levels are available: low alert $\left(0.2<M_{\mathrm{c}}<2 \mathrm{mg} \mathrm{m}^{-3}\right)$, medium alert $\left(2<M_{\mathrm{c}}<\right.$ $\left.4 \mathrm{mg} \mathrm{m}^{-3}\right)$, and high alert $\left(M_{\mathrm{c}}>4 \mathrm{mg} \mathrm{m}^{-3}\right)$, indicating the increasing amount of dust particles that are likely dangerous for flight operations. The coarse backscatter coefficient due to the highly depolarizing particles is estimated first. Next, the coarse backscatter coefficient is checked, and the level of alert is decided. Furthermore, to avoid isolated false alarms in the EWS product, we incorporated a linear spatial smoothing filter. It is the average of the pixels contained in the neighborhood of each pixel, for which we defined a 3 pixel $\times 3$ pixel grid. A similar methodology has been demonstrated within an international demonstration exercise for the purpose of the EUNADICS-AV project, in which an artificial Mount Etna eruption was simulated (Hirtl et al., 2020).

\section{Results}

In this section, we apply the described methodology to potential perilous events recently detected by the stations of Finokalia and Antikythera, Greece. The observations refer to the same lidar system that was initially deployed in Finokalia and later moved to the island of Antikythera. The aim is not to present a detailed analysis of investigated cases but instead to demonstrate the potential of this methodology to be integrated as a tailored EARLINET product for the fast alerting of airborne hazards relevant to flight operations.

\subsection{Desert dust particle case}

During March 2018, frequent intense dust storms affected Greece with the region of Libya being the originating source (Kaskaoutis et al., 2019). Strong surface and middle and upper troposphere Khamsin winds transported dust northwards for four distinct periods (i.e., 4-7, 17, 21-22, 25-26 March). Solomos et al. (2018) examined in detail the record-breaking episode of 21-22 March, when surface concentrations exceeded $6 \mathrm{mg} \mathrm{m}^{-3}$ on 22 March and resulted in the closure of the Heraklion airport.

Here we focus on 21 March when the dust cloud initially appeared over Crete. Figure 5 shows the dust map derived from SEVIRI data along with the cloud cover at 12:00 UTC. The dusty pixels are depicted in two different colors as a function of the confidence levels of the dust detection scheme (i.e., brown means high confidence and orange mid-low con- 


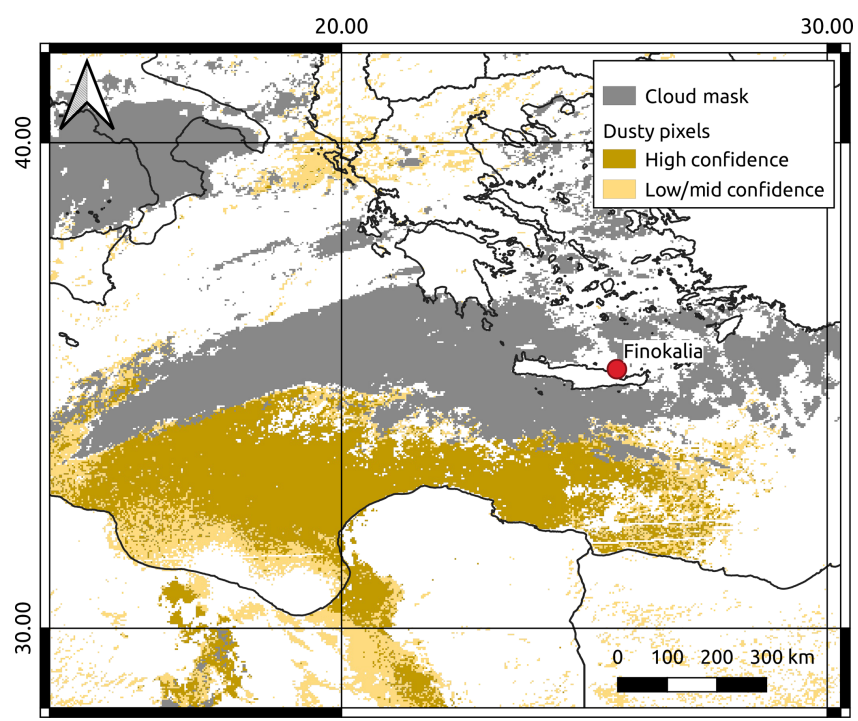

Figure 5. The dust SEVIRI product (Marchese et al., 2017) at 12:00 UTC on 21 March 2018 is represented in confidence levels (i.e., brown pixels refer to high confidence and orange pixels to mid-low confidence). The gray pixels indicate the cloud cover.

Valid: 2018-03-21_12:00:00

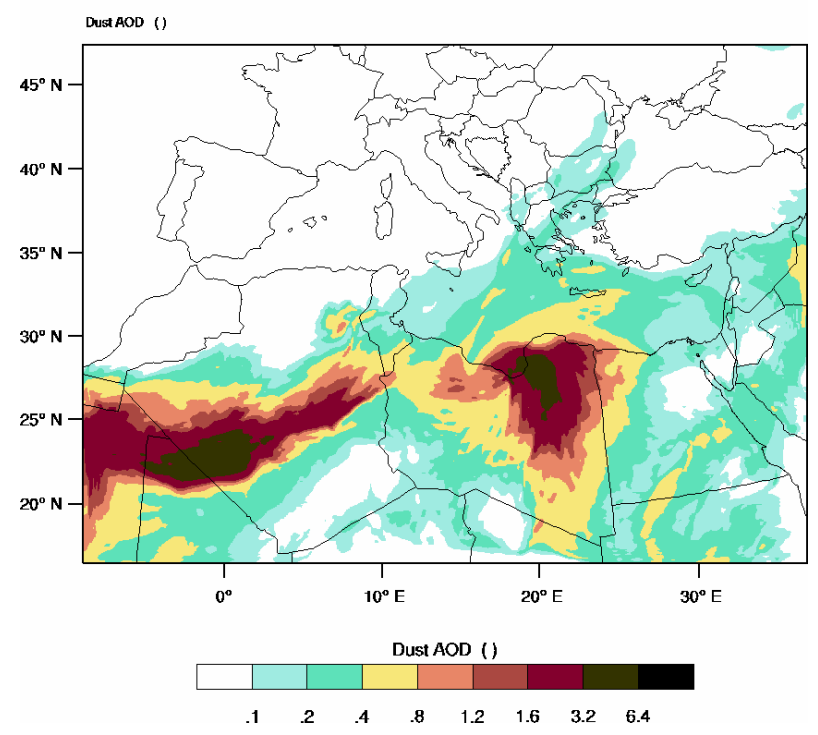

Figure 6. WRF-Chem dust aerosol optical depth (AOD) on 21 March 2018 12:00 UTC.

fidence). In particular, the dust cloud moves from northern Africa towards the eastern Mediterranean, where the cloud cover impedes the dust detection over insular Greece, although the map demonstrates the intensity and the geographic extent of the dust event. The situation of the dust transport at 12:00 UTC on 21 March 2018 is also evident from the WRF-Chem (WRF model coupled with Chemistry) dust aerosol optical depth (AOD) in Fig. 6. The entire eastern
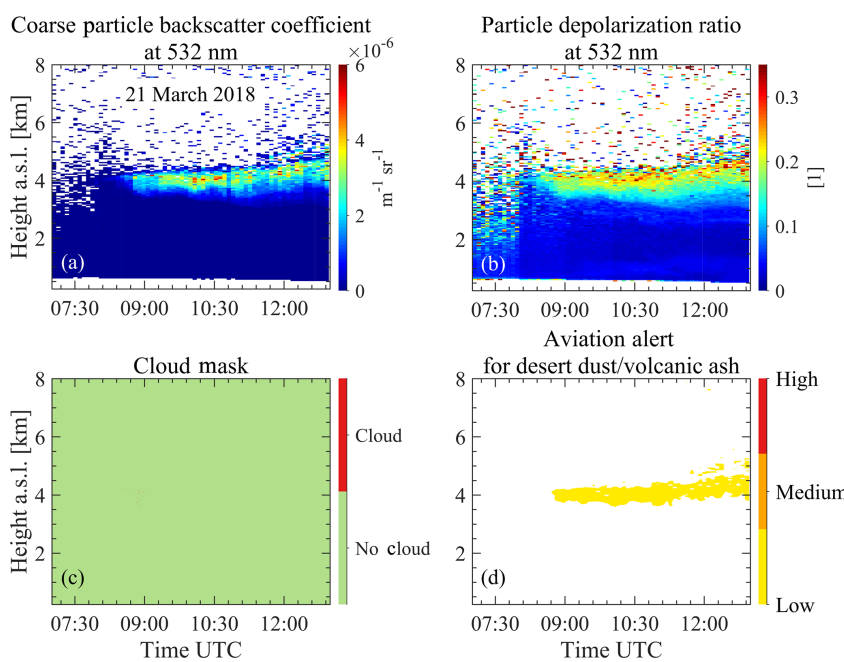

Figure 7. EARLINET observations at Finokalia on 21 March 2018: (a) the coarse particle backscatter coefficient at $532 \mathrm{~nm}$, (b) the particle depolarization ratio at $532 \mathrm{~nm}$, (c) the cloud screening output, and (d) the alert for aviation. Note that the cloud screening product is given at its full resolution - i.e., the vertical resolution is $7.5 \mathrm{~m}$, and the temporal resolution is $30 \mathrm{~s}-$ and all the other products have a resolution of $30 \mathrm{~m}$ and $5 \mathrm{~min}$ instead.

Mediterranean is affected by this episode, and the simulated AOD exceeds 0.4 over certain parts of eastern Crete near the Finokalia station.

The coarse particle backscatter coefficient, the particle depolarization ratio at $532 \mathrm{~nm}$ (as described in Sect. 3.1), the cloud mask, and the tailored product for the period 07:0013:00 UTC are shown in Fig. 7. The dust particles arrive over Finokalia around 08:00 UTC in a filament-like layer of about $4 \mathrm{~km}$, wherein the dust particles exhibit high values of the particle depolarization ratio. Figure $7 \mathrm{~d}$ shows the alert product for aviation, which demonstrates a low level alert indicating a considerable amount of dust particles in the troposphere that are likely dangerous for flight operations. In particular, the coarse particle backscatter coefficient at $532 \mathrm{~nm}$ exhibits values up to $6 \times 10^{-6} \mathrm{~m}^{-1} \mathrm{sr}^{-1}$, which exceeds the threshold value of $1.7 \times 10^{-6} \mathrm{~m}^{-1} \mathrm{sr}^{-1}$. In addition, this case illustrates the advantage of a ground-based lidar system to operate below high clouds that obstruct satellite observations (see Fig. 5) and, therefore, provides important insight.

As the event was aggravated in the following hours, the lidar signal is most likely attenuated which highlights the limitation of the methodology. However, the alert delivery could act as a pre-alerting tool for aviation by pinpointing the specific aerosol conditions. A similar approach for airport operations has been developed using automatic lidars and ceilometers for the prediction of fog formation (Haeffelin et al., 2016). 

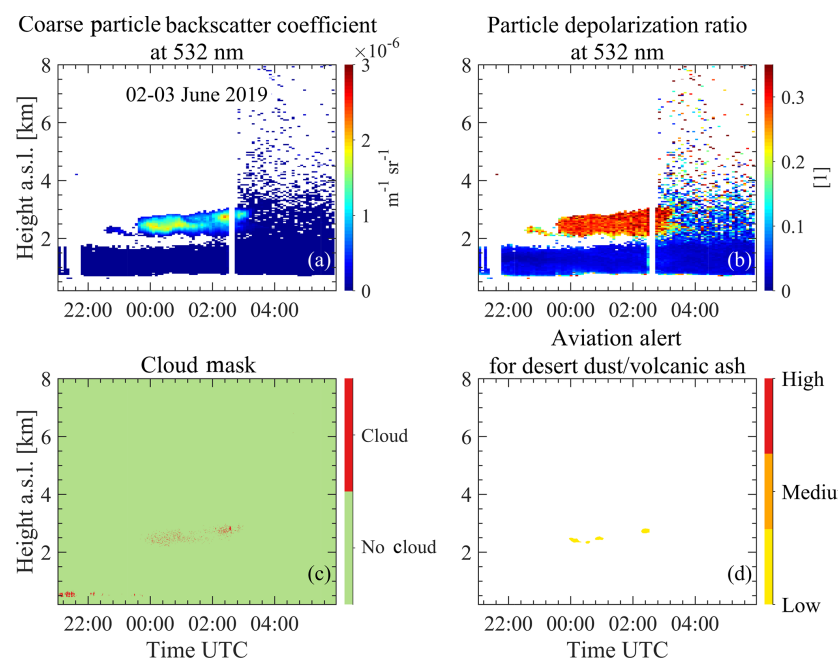

Aviation alert

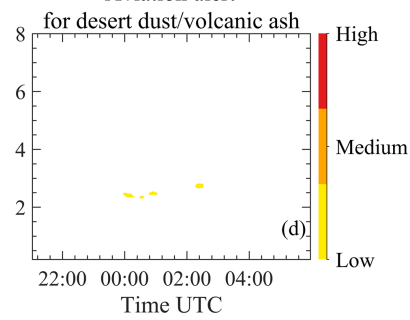

Figure 8. EARLINET observations at Antikythera on 23 June 2019: (a) the coarse particle backscatter coefficient at $532 \mathrm{~nm}$, (b) the particle depolarization ratio at $532 \mathrm{~nm}$, (c) the cloud screening output, and (d) the alert for aviation. Note that the cloud screening product is given at its full resolution - i.e., the vertical resolution is $7.5 \mathrm{~m}$, and the temporal resolution is $30 \mathrm{~s}-$ and all the other products have a resolution of $30 \mathrm{~m}$ and $5 \mathrm{~min}$ instead.

\subsection{Volcanic and desert dust particle case}

The eruption of the volcano Mount Etna which began in the early hours of 30 May 2019 injected ash into the atmosphere at an altitude of 3.5-4.0 km (Toulouse Volcanic Ash Advisory Center report at 11:21 UTC, 30 May). The volcanic activity ceased most likely on 3 June (https://ingvvulcani. wordpress.com, last access: 31 October 2019). This volcanic activity did not lead to any air traffic disruption, as was the case for the explosion on 20 July. The latter caused flight rerouting and delays (Amato, 2019).

Aerosol particles of possibly volcanic origin were monitored with the multi-wavelength lidar of NOA over Antikythera, Greece. The eastward advection of volcanic particles from Mount Etna presents a common pathway and has been previously investigated by means of active remote sensing (e.g., Hughes et al., 2016; Zerefos et al., 2006). The presence of these elevated layers above Greece could be a result of the continuous Mount Etna activity of the past few days. Figure 8 shows two distinct layers with different characteristics for the period from 21:00 UTC on 2 June to 06:00 UTC on 3 June. The first layer is initially observed between 1 and $2 \mathrm{~km}$ on 2 June and remains visible for the rest of the temporal window. The particle backscatter coefficient is around $1 \times 10^{-6} \mathrm{~m}^{-1} \mathrm{sr}^{-1}$, and the particle depolarization ratio is below $5 \%$ and differentiates from the second layer above. The second layer is seen after 23:30 UTC on 2 June until 03:00 UTC on 3 June and resides in the range of $2-3 \mathrm{~km}$. The layer particle depolarization ratio is well above $20 \%$ and indicates non-spherical particles. Moreover, it exhibits a higher

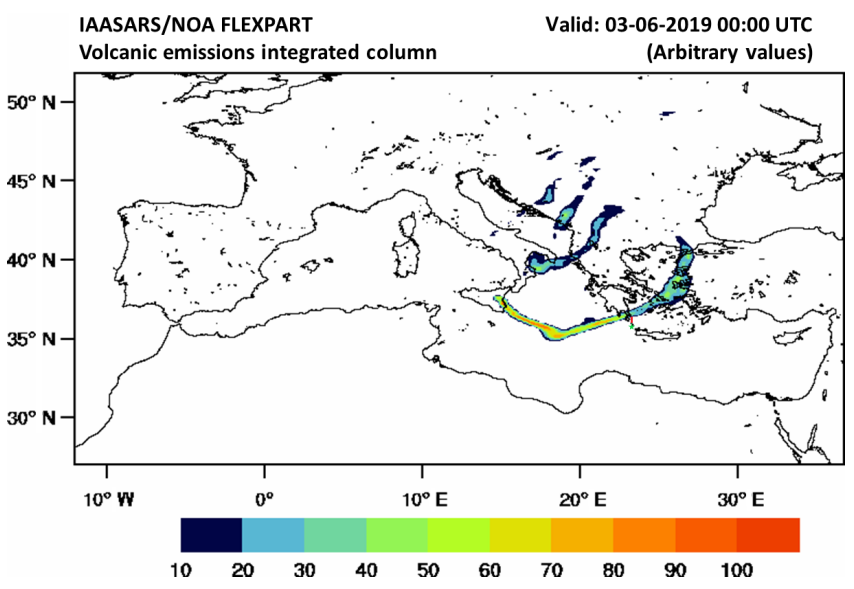

Figure 9. FLEXPART vertically integrated volcanic ash particles (arbitrary values) originating from Mount Etna on 3 June 2019 at 00:00 UTC. The green star indicates the location of Antikythera, and the red line is the misplacement of the simulated plume from the lidar station.

particle backscatter coefficient $\left(\sim 3 \times 10^{-6} \mathrm{~m}^{-1} \mathrm{sr}^{-1}\right)$. As a result, the alert is triggered for the latter. It is noteworthy that, as seen in the cloud mask, few pixels within the same aerosol layer are wrongly classified as clouds and are used instead in the alert delivery. The improvement of the cloud masking module is currently ongoing and is expected to eliminate false cloud detection, but nonetheless the aerosol layer is very well captured by the method.

The identification of the source of the two aerosol layers is made through an analysis of FLEXPART and WRFChem simulations. Figure 9 indicates the eastward transport of a relatively thin $(\sim 60 \mathrm{~km}$ horizontal width) volcanic ash plume from Mount Etna towards Greece. As shown by the FLEXPART simulation, this plume propagated eastwards from Sicily towards the Ionian Sea, reaching parts of southern Greece. The simulated plume is misplaced by about $70 \mathrm{~km}$ towards the north from the EARLINET Antikythera station; however, its vertical structure is still evident in the cross section of Fig. 10. The eastward motion and the vertical profile of simulated aerosol volcanic plume corroborate the existence of volcanic particles in the upper layer of Fig. 8. The non-depolarizing structures below $2 \mathrm{~km}$ are sea-salt particles possibly mixed with dust particles. Limited concentrations $\left(>0.04 \mathrm{mg} \mathrm{m}^{-3}\right)$ of dust are simulated at these heights by the WRF-Chem model (Fig. 11) and are accompanied by increased relative humidity near the surface, thus implying hygroscopic growth and more spherical particles in this area. In synthesis, both observations and model simulations advocate for the identification of likely volcanic dust and aged desert dust particles in the same aerosol scene but in separate layers. Consequently, the alert delivered refers to volcanic dust. 
Table 2. EARLINET stations that participated in the EUNADICS-AV exercise during 5-6 March 2019. The percentage of the measurements made for the 2 consecutive days and the specific temporal windows is reported. The " $\mathrm{X}$ " denotes the stations for which it was possible to derive the alert for aviation - i.e., the availability of a calibrated backscatter coefficient and depolarization ratio of $532 \mathrm{~nm}$.

\begin{tabular}{|c|c|c|c|}
\hline \multirow{2}{*}{ EARLINET station } & \multicolumn{2}{|c|}{ Measurements performed (\%) } & \multirow{2}{*}{ EWS } \\
\hline & $\begin{array}{r}5 \text { March, } \\
11: 00-17: 00 \text { UTC }\end{array}$ & $\begin{array}{r}\text { 6 March, } \\
07: 00-12: 00 \text { UTC }\end{array}$ & \\
\hline Antikythera (GR) & 100 & 100 & $X$ \\
\hline Athens* (GR) & 100 & 100 & \\
\hline Barcelona (ES) & 100 & 0 & $\mathrm{X}$ \\
\hline Belgrade* $^{*}$ (SRB) & 100 & 100 & \\
\hline Clermont-Ferrand* (FR) & 33 & 40 & \\
\hline Cluj* (RO) & 100 & 80 & \\
\hline Granada (ES) & 17 & 20 & $X$ \\
\hline Hohenpeissenberg (DE) & 100 & 100 & $X$ \\
\hline Leipzig (DE) & 100 & 100 & $\mathrm{X}$ \\
\hline Madrid (ES) & 33 & 0 & \\
\hline Potenza (IT) & 100 & 100 & $\mathrm{X}$ \\
\hline Rome - Tor Vergata (IT) & 100 & 100 & \\
\hline Thessaloniki* (GR) & 83 & 100 & \\
\hline
\end{tabular}

The * indicates the stations equipped with a depolarization channel, although this information was not available during the exercise.

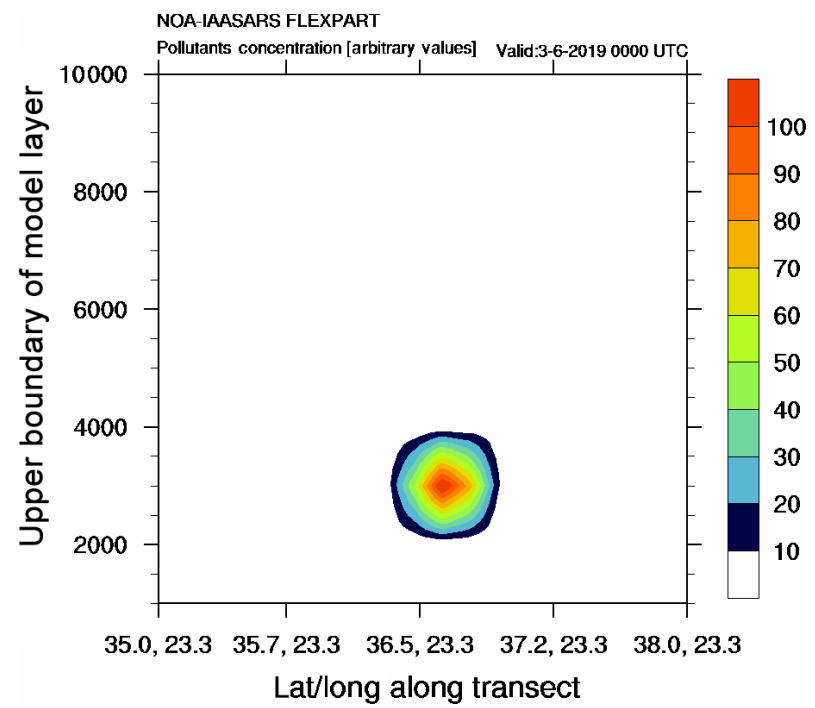

Figure 10. FLEXPART vertical cross section of the simulated volcanic particles (in arbitrary values) over the greater Antikythera region. The exact location of the cross section is indicated by the red line in Fig. 9.

\subsection{Lessons learned from the EUNADICS-AV exercise}

The application of the EWS and the timely delivery of the EARLINET data were tested in real time during the EUNADICS-AV exercise, in which EARLINET stations performed synchronous measurements. The EUNADICS-AV demonstration exercise in March 2019, based on a fictitious volcanic eruption, demonstrated that tailored observations, as well as model services, can profitably support aviation stakeholders (Hirtl et al., 2020).

In particular, 13 EARLINET stations contributed to the exercise according to a predefined measurement schedule i.e., from 11:00 to 17:00 UTC on 5 March 2019 and from 07:00 to 11:00 UTC on 6 March 2019 - independent of the station's capabilities with respect to the EWS. This decision stems from the opportunity to assess the sequence of procedures for real-time data retrieval and data visualization. In addition, the measurements schedule, the stations submitted raw lidar data to the SCC server every hour, which were automatically available on the EARLINET Quicklook Interface (https://quicklooks.earlinet.org/, last access: 16 January 2019). For the majority of the stations and temporal windows, low clouds and cirrus clouds were observed. Table 2 summarizes the measurements gathered per hour segment and the station capabilities with respect to the EWS. In total, $73 \%$ of the measurements were performed successfully, whereas rain and staffing the stations mostly inhibited the rest. Moreover, only for six of the stations was it possible to retrieve the tailored product mainly because of the lack of the depolarization information during the exercise. The tailored product did not produce any alert as the aerosol layers were neither volcanic dust nor desert dust, and they did not yield high backscatter coefficient values. Hence, results of the exercise are not shown here; nonetheless, the EARLINET observations are available through the EARLINET Quicklook Interface.

Overall, the raw lidar data were streamed and processed in less than $30 \mathrm{~min}$ from the measurement, enabling the timely delivery of the lidar data and the tailored product when pos- 


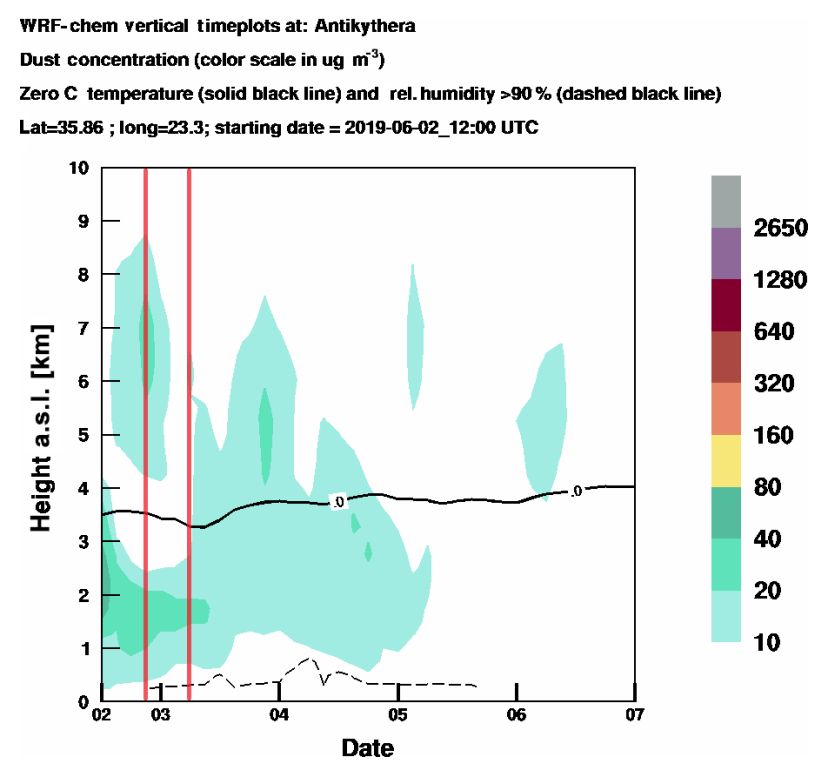

Figure 11. WRF-Chem time-height cross section of simulated dust concentration $\left(\mu \mathrm{g} \mathrm{m}^{-3}\right)$ over Antikythera starting on 2 June at 12:00 UTC. The solid black line is the $0^{\circ} \mathrm{C}$ isotherm, and the dashed black line indicates $90 \%$ relative humidity. The red lines correspond to the time domain of the lidar observations - i.e., from 21:00 UTC on 2 June 2019 until 06:00 UTC on 3 June 2019.

sible. Furthermore, the demonstration exercise was the first occasion in which the proposed methodology was tested in NRT, and the obtained results suggest that the network could actively support stakeholders in decision-making during an aviation crisis.

\section{Conclusions}

A tailored product for aviation hazards by means of highresolution lidar data has been proposed for the first time to our knowledge. In particular, the methodology employs single-wavelength EARLINET high-resolution data (i.e., $532 \mathrm{~nm}$ calibrated backscatter coefficient and $532 \mathrm{~nm}$ calibrated volume linear depolarization ratio) and yields NRT alerts based on established aerosol mass concentration thresholds. The methodology aims to provide an EARLINET EWS for the fast alerting of airborne hazards exploiting the SCC advancements and to mitigate the effects of a future aviation crisis. The application on EARLINET data from the eastern Mediterranean demonstrated the strength of the methodology in identifying possible dangers for aviation from volcanic ash and desert dust plumes.

One of the key challenges for a NRT automated alert delivery is the calibration of the backscatter and depolarization profiles as the elastic and depolarization channels are used. The EARLINET SCC ensures the absolute calibration of the lidar signals. As a source of high uncertainties in the retrieval of the particle backscatter coefficient, the inference of the lidar ratio was acknowledged. Accordingly, an iterative method has been developed to work with high-resolution lidar data, which compares well with particle backscatter coefficient profiles retrieved with the Raman method.

Additionally, and equally important in the alert delivery approach, there is the conversion factor with which the mass concentration thresholds are converted into a particle backscatter coefficient. The AERONET-derived conversion factors are known to be restricted by the AERONET data inversion scheme and to underestimate large to giant particles. Therefore, the selected conversion factor was chosen (i.e., $0.9 \times 10^{-6} \mathrm{~m}$ ) as the maximum value of the literature review with reference to fresh volcanic and desert dust observations.

The NRT operation of EARLINET during the EUNADICS-AV exercise was successfully demonstrated. The successful application of the method in NRT has been achieved during the EUNADICS-AV exercise. The raw data, upon being uploaded to the SCC server, were automatically processed and became freely accessible through the EARLINET portal and available in order to initiate the alert delivery. The exercise demonstrated the strength of the network, which, if promptly triggered, can enable measurements in the case of natural hazards for aviation.

In addition, a similar approach can be extended to lidar systems operated by the European volcano observatories. Two examples of such observatories in Europe are the Istituto Nazionale di Geofisica e Vulcanologia - Osservatorio Etneo (INGV-OE) and the Icelandic Meteorological Office (IMO). INGV-OE is responsible for monitoring Mount Etna, while IMO is responsible for monitoring all volcanic activity in Iceland.

This method is highly versatile as it can adapt to other wavelengths, and the aerosol backscatter thresholds can be set to accommodate different volcanic and desert dust scenarios by adjusting the conversion factor, the lidar ratio, the bulk density, and the mass concentration levels. In addition, even if developed on the basis of EARLINET, it can be applied to such lidar systems as those that are part of Galion (ADNet, LALINET, MPLNET), as well as to current (CALIPSO; Cloud-Aerosol Lidar and Infrared Pathfinder Satellite Observation) and future (EarthCARE; Earth Clouds, Aerosols and Radiation Explorer) lidar-based satellite missions.

Code availability. The code is available upon request (contact mail: nikolaos.papagiannopoulos@imaa.cnr.it).

Data availability. The EARLINET data are accessible through the EARLINET database web portal https://data.earlinet.org (login required, last access: 10 September 2020).

Author contributions. The conceptualization and design of this study were carried out by NP and LM. GD is the lead scientist and 
curator of the EARLINET SCC data. IM and IB created the calibration and cloud mask module for the EARLINET SCC, respectively. VA and AG are the principal investigator (PI) and data originator for the EARLINET stations of Finokalia and Antikythera, respectively. SS and AK performed FLEXPART model simulations for the Antikythera case study. AF retrieved the dust product from SEVIRI data for the Finokalia case study. AA, AC, AP, ARG, DD, DM, FM, HB, IM, LAA, NA, PF, VM, and ZM are either the PIs or the key personnel of the stations involved in the measurements exercise and ensured the high-quality operation of the respective lidars. The interpretation of results was determined from discussions involving all authors. The original draft of the paper was written by NP and reviewed and edited by all the coauthors.

Competing interests. The authors declare that they have no conflict of interest.

Special issue statement. This article is part of the special issue "EARLINET aerosol profiling: contributions to atmospheric and climate research". It is not associated with a conference.

Acknowledgements. The authors acknowledge EARLINET for providing aerosol lidar profiles (https://www.earlinet.org, last access: 31 October 2019). We thank the ACTRIS-2 and ACTRIS preparatory phase projects that have received funding from the European Union's Horizon 2020 Framework Program for Research and Innovation (grant agreement no. 654109) and from European Union's Horizon 2020 Coordination and Support Action (grant agreement no. 739530), respectively. This work has been conducted within the framework of the EUNADICS-AV project, which has received funding from the European Union's Horizon 2020 research program for Societal Challenges - Smart, Green and Integrated Transport under grant agreement no. 723986. Furthermore, the research leading to these results has received funding from the COST Action CA16202, supported by the COST Association (European Cooperation in Science and Technology). The project e-shape (EuroGEOSS Showcases: Applications Powered by Europe), funded under the European Union's Horizon 2020 program (grant agreement no. 820852), is also acknowledged. Part of the work performed for this study was funded by the Ministry of Research and Innovation through Program I - Development of the National Research-Development System, subprogram 1.2 - Institutional Performance - Projects of Excellence Financing in RDI (grant no. 19PFE/17.10.2018) and by the Romanian National Core Program (grant no. 18N/2019). VA acknowledges support of this work by the European Research Council (ERC) under the European Community's Horizon 2020 Framework Program for Research and Innovation grant agreement 725698 (D-10 TECT).

Financial support. This research has been supported by the ACTRIS-2 (grant no. 654109), the ACTRIS preparatory phase (grant no. 739530), the EUNADICS-AV (grant no. 723986), the E-shape (EuroGEOSS Showcases: Applications Powered by Europe) (grant no. 820852), the Ministry of Research and Innovation through Program I - Development of the National Research-
Development System, Subprogram 1.2 - Institutional Performance - Projects of Excellence Financing in RDI (grant no. 19PFE/17.10.2018), the Romanian National Core Program (grant no. 18N/2019), and the European Commission, H2020 Research Infrastructures (D-TECT (grant no. 725698)).

Review statement. This paper was edited by Eduardo Landulfo and reviewed by three anonymous referees.

\section{References}

Amato, G.: Cenere dall'Etna, disagi in mattinata all'aeroporto di Catania, La Repubblica, available at: https://palermo.repubblica. it/cronaca/2019/07/20/news/cenere_dall_etna_disagi_all_ aeroporto_di_catania-231613901/?ref=search (last access: 10 September 2020), 2019 (in Italian).

Ansmann, A., Tesche, M., Groß, S., Freudenthaler, V., Seifert, P., Hiebsch, A., Schmidt, J., Wandinger, U., Mattis, I., Müller, D., and Wiegner, M.: The 16 April 2010 major volcanic ash plume over central Europe: EARLINET lidar and AERONET photometer observations at Leipzig and Munich, Germany, Geophys. Res. Lett., 37, L13810, https://doi.org/10.1029/2010GL043809, 2010.

Ansmann, A., Tesche, M., Seifert, P., Groß, S., Freudenthaler, V., Apituley, A., Wilson, K. M., Serikov, I., Linné, H., Heinold, B., Hiebsch, A., Schnell, F., Schmidt, J., Mattis, I., Wandinger, U., and Wiegner, M.: Ash and fine-mode particle mass profiles from EARLINET-AERONET observations over central Europe after the eruptions of the Eyjafjallajökull volcano in 2010, J. Geophys. Res.-Atmos., 116, D00U02, https://doi.org/10.1029/2010JD015567, 2011.

Ansmann, A., Seifert, P., Tesche, M., and Wandinger, U.: Profiling of fine and coarse particle mass: case studies of Saharan dust and Eyjafjallajökull/Grimsvötn volcanic plumes, Atmos. Chem. Phys., 12, 9399-9415, https://doi.org/10.5194/acp12-9399-2012, 2012.

Ansmann, A., Mamouri, R.-E., Hofer, J., Baars, H., Althausen, D., and Abdullaev, S. F.: Dust mass, cloud condensation nuclei, and ice-nucleating particle profiling with polarization lidar: updated POLIPHON conversion factors from global AERONET analysis, Atmos. Meas. Tech., 12, 4849-4865, https://doi.org/10.5194/amt-12-4849-2019, 2019.

Baars, H., Seifert, P., Engelmann, R., and Wandinger, U.: Target categorization of aerosol and clouds by continuous multiwavelength-polarization lidar measurements, Atmos. Meas. Tech., 10, 3175-3201, https://doi.org/10.5194/amt-103175-2017, 2017.

Behrendt, A. and Nakamura, T.: Calculation of the calibration constant of polarization lidar and its dependency on atmospheric temperature, Opt. Express, 10, 805-817, https://doi.org/10.1364/OE.10.000805, 2002.

Binietoglou, I.: Synergies of ground-based remote sensing techniques for aerosol mass profiling, $\mathrm{PhD}$ thesis, University of Basilicata, 139 pp., 2014.

Binietoglou, I., Basart, S., Alados-Arboledas, L., Amiridis, V., Argyrouli, A., Baars, H., Baldasano, J. M., Balis, D., Belegante, L., Bravo-Aranda, J. A., Burlizzi, P., Carrasco, V., Chaikovsky, A., Comerón, A., D’Amico, G., Filioglou, M., Granados- 
Muñoz, M. J., Guerrero-Rascado, J. L., Ilic, L., Kokkalis, P., Maurizzi, A., Mona, L., Monti, F., Muñoz Porcar, C., Nicolae, D., Papayannis, A., Pappalardo, G., Pejanovic, G., Perreira, S., Perrone, M., Pietruczuk, A., Posyniak, M., Rocadenbosch, F., Rodríguez-Gómez, A., Sicard, M., Siomos, N., Szkop, A., Taradellas, E., Tsekeri, A., Vukovic, A., Wandinger, U., and Wagner, J.: A methodology for investigating dust model performance using synergistic EARLINET/AERONET dust concentration retrievals, Atmos. Meas. Tech., 8, 3577-3600, https://doi.org/10.5194/amt-8-3577-2015, 2015.

Bolic, T. and Sivcev, Z.: Eruption of Eyjafjallajökull in Iceland: Experience of European Air Traffic Management, Trans. Res. Record, 2214, 136-143, https://doi.org/10.3141/2214-17, 2011.

Brioude, J., Arnold, D., Stohl, A., Cassiani, M., Morton, D., Seibert, P., Angevine, W., Evan, S., Dingwell, A., Fast, J. D., Easter, R. C., Pisso, I., Burkhart, J., and Wotawa, G.: The Lagrangian particle dispersion model FLEXPART-WRF version 3.1, Geosci. Model Dev., 6, 1889-1904, https://doi.org/10.5194/gmd-6-18892013, 2013.

Chaikovsky, A., Dubovik, O., Holben, B., Bril, A., Goloub, P., Tanré, D., Pappalardo, G., Wandinger, U., Chaikovskaya, L., Denisov, S., Grudo, J., Lopatin, A., Karol, Y., Lapyonok, T., Amiridis, V., Ansmann, A., Apituley, A., Alados-Arboledas, L., Binietoglou, I., Boselli, A., D'Amico, G., Freudenthaler, V., Giles, D., Granados-Muñoz, M. J., Kokkalis, P., Nicolae, D., Oshchepkov, S., Papayannis, A., Perrone, M. R., Pietruczuk, A., Rocadenbosch, F., Sicard, M., Slutsker, I., Talianu, C., De Tomasi, F., Tsekeri, A., Wagner, J., and Wang, X.: Lidar-Radiometer Inversion Code (LIRIC) for the retrieval of vertical aerosol properties from combined lidar-radiometer data: development and distribution in EARLINET, Atmos. Meas. Tech., 9, 1181-1205, https://doi.org/10.5194/amt-9-1181-2016, 2016.

Córdoba-Jabonero, C., Sicard, M., Ansmann, A., del Águila, A., and Baars, H.: Separation of the optical and mass features of particle components in different aerosol mixtures by using POLIPHON retrievals in synergy with continuous polarized Micro-Pulse Lidar (P-MPL) measurements, Atmos. Meas. Tech., 11, 4775-4795, https://doi.org/10.5194/amt-114775-2018, 2018.

D’Amico, G., Amodeo, A., Baars, H., Binietoglou, I., Freudenthaler, V., Mattis, I., Wandinger, U., and Pappalardo, G.: EARLINET Single Calculus Chain-overview on methodology and strategy, Atmos. Meas. Tech., 8, 4891-4916, https://doi.org/10.5194/amt-8-4891-2015, 2015.

D’Amico, G., Amodeo, A., Mattis, I., Freudenthaler, V., and Pappalardo, G.: EARLINET Single Calculus Chain - technical - Part 1: Pre-processing of raw lidar data, Atmos. Meas. Tech., 9, 491507, https://doi.org/10.5194/amt-9-491-2016, 2016.

Devenish, B., Thomson, D., Marenco, F., Leadbetter, S., Ricketts, H., and Dacre, H.: A study of the arrival over the United Kingdom in April 2010 of the Eyjafjallajökull ash cloud using ground-based lidar and numerical simulations, Atmos. Environ., 48, 152-164, 2012.

Di Girolamo, P., Ambrico, P. F., Amodeo, A., Boselli, A., Pappalardo, G., and Spinelli, N.: Aerosol observations by lidar in the nocturnal boundary layer, Appl. Opt., 38, 4585-4595, https://doi.org/10.1364/AO.38.004585, 1999.
Eliasson, J., Watson, I. M., and Weber, K.: Volcanic Ash: Hazard Observation, In Situ Observations of Airborne Ash From Manned Aircraft, Elsevier, 89-98, 2016.

Engelmann, R., Kanitz, T., Baars, H., Heese, B., Althausen, D., Skupin, A., Wandinger, U., Komppula, M., Stachlewska, I. S., Amiridis, V., Marinou, E., Mattis, I., Linné, H., and Ansmann, A.: The automated multiwavelength Raman polarization and water-vapor lidar PollyXT: the neXT generation, Atmos. Meas. Tech., 9, 1767-1784, https://doi.org/10.5194/amt-9-1767-2016, 2016.

Freudenthaler, V., Esselborn, M., Wiegner, M., Heese, B., Tesche, M., Ansmann, A., Müller, D., Althausen, D., Wirth, M., Fix, A., Ehret, G., Knippertz, P., Toledano, C., Gasteiger, J., Garhammer, M., and Seefeldner, M.: Depolarization ratio profiling at several wavelengths in pure Saharan dust during SAMUM 2006, Tellus B, 61, 165-179, https://doi.org/10.1111/j.16000889.2008.00396.x, 2009.

Gasteiger, J., Groß, S., Freudenthaler, V., and Wiegner, M.: Volcanic ash from Iceland over Munich: mass concentration retrieved from ground-based remote sensing measurements, Atmos. Chem. Phys., 11, 2209-2223, https://doi.org/10.5194/acp11-2209-2011, 2011.

Goudie, A. and Middleton, N. J.: Desert Dust in the Global System, Springer-Verlag Berlin Heidelberg, 287 pp., https://doi.org/10.1007/3-540-32355-4, 2006.

Granados-Muñoz, M. J., Navas-Guzmán, F., Guerrero-Rascado, J. L., Bravo-Aranda, J. A., Binietoglou, I., Pereira, S. N., Basart, S., Baldasano, J. M., Belegante, L., Chaikovsky, A., Comerón, A., D’Amico, G., Dubovik, O., Ilic, L., Kokkalis, P., Muñoz Porcar, C., Nickovic, S., Nicolae, D., Olmo, F. J., Papayannis, A., Pappalardo, G., Rodríguez, A., Schepanski, K., Sicard, M., Vukovic, A., Wandinger, U., Dulac, F., and AladosArboledas, L.: Profiling of aerosol microphysical properties at several EARLINET/AERONET sites during the July 2012 ChArMEx/EMEP campaign, Atmos. Chem. Phys., 16, 70437066, https://doi.org/10.5194/acp-16-7043-2016, 2016.

Guffanti, M., Schneider, D. J., Wallace, K. L., Hall, T., Bensimon, D. R., and Salinas, L. J.: Aviation response to a widely dispersed volcanic ash and gas cloud from the August 2008 eruption of Kasatochi, Alaska, USA, J. Geophys. Res.-Atmos., 115, D00L19, https://doi.org/10.1029/2010JD013868, 2010.

Haeffelin, M., Laffineur, Q., Bravo-Aranda, J.-A., Drouin, M.-A., Casquero-Vera, J.-A., Dupont, J.-C., and De Backer, H.: Radiation fog formation alerts using attenuated backscatter power from automatic lidars and ceilometers, Atmos. Meas. Tech., 9, 53475365, https://doi.org/10.5194/amt-9-5347-2016, 2016.

Hirtl, M., Arnold, D., Baro, R., Brenot, H., Coltelli, M., Eschbacher, K., Hard-Stremayer, H., Lipok, F., Maurer, C., Meinhard, D., Mona, L., Mulder, M. D., Papagiannopoulos, N., Pernsteiner, M., Plu, M., Robertson, L., Rokitansky, C.-H., Scherllin-Pirscher, B., Sievers, K., Sofiev, M., Som de Cerff, W., Steinheimer, M., Stuefer, M., Theys, N., Uppstu, A., Wagenaar, S., Winkler, R., Wotawa, G., Zobl, F., and Zopp, R.: A volcanic-hazard demonstration exercise to assess and mitigate the impacts of volcanic ash clouds on civil and military aviation, Nat. Hazards Earth Syst. Sci., 20, 1719-1739, https://doi.org/10.5194/nhess20-1719-2020, 2020.

Hughes, E. J., Yorks, J., Krotkov, N. A., da Silva, A. M., and McGill, M.: Using CATS near-real-time lidar observations to monitor and 
constrain volcanic sulfur dioxide (SO2) forecasts, Geophys. Res. Lett., 43, 11089-11097, https://doi.org/10.1002/2016GL070119, 2016.

Jones, S. L., Adams-Selin, R., Hunt, E. D., Creighton, G. A., and Cetola, J. D.: Update on modifications to WRF-CHEM GOCART for fine-scale dust forecasting at AFWA, in: AGU Fall Meeting Abstracts, A33D-0188, 2012.

Kaskaoutis, D., Rashki, A., Dumka, U., Mofidi, A., Kambezidis, H., Psiloglou, B., Karagiannis, D., Petrinoli, K., and Gavriil, A.: Atmospheric dynamics associated with exceptionally dusty conditions over the eastern Mediterranean and Greece in March 2018, Atmos. Res., 218, 269-284, https://doi.org/10.1016/j.atmosres.2018.12.009, 2019.

Lopatin, A., Dubovik, O., Chaikovsky, A., Goloub, P., Lapyonok, T., Tanré, D., and Litvinov, P.: Enhancement of aerosol characterization using synergy of lidar and sun-photometer coincident observations: the GARRLiC algorithm, Atmos. Meas. Tech., 6, 2065-2088, https://doi.org/10.5194/amt-6-2065-2013, 2013.

Madonna, F., Rosoldi, M., Lolli, S., Amato, F., Vande Hey, J., Dhillon, R., Zheng, Y., Brettle, M., and Pappalardo, G.: Intercomparison of aerosol measurements performed with multiwavelength Raman lidars, automatic lidars and ceilometers in the framework of INTERACT-II campaign, Atmos. Meas. Tech., 11, 2459-2475, https://doi.org/10.5194/amt-11-2459-2018, 2018.

Mamali, D., Marinou, E., Sciare, J., Pikridas, M., Kokkalis, P., Kottas, M., Binietoglou, I., Tsekeri, A., Keleshis, C., Engelmann, R., Baars, H., Ansmann, A., Amiridis, V., Russchenberg, H., and Biskos, G.: Vertical profiles of aerosol mass concentration derived by unmanned airborne in situ and remote sensing instruments during dust events, Atmos. Meas. Tech., 11, 2897-2910, https://doi.org/10.5194/amt-11-2897-2018, 2018.

Mamouri, R. E. and Ansmann, A.: Fine and coarse dust separation with polarization lidar, Atmos. Meas. Tech., 7, 3717-3735, https://doi.org/10.5194/amt-7-3717-2014, 2014.

Mamouri, R.-E. and Ansmann, A.: Potential of polarization/Raman lidar to separate fine dust, coarse dust, maritime, and anthropogenic aerosol profiles, Atmos. Meas. Tech., 10, 3403-3427, https://doi.org/10.5194/amt-10-3403-2017, 2017.

Marchese, F., Sannazzaro, F., Falconieri, A., Filizzola, C., Pergola, N., and Tramutoli, V.: An Enhanced Satellite-Based Algorithm for Detecting and Tracking Dust Outbreaks by Means of SEVIRI Data, Remote Sens., 9, 537, https://doi.org/10.3390/rs9060537, 2017.

Mattis, I., D’Amico, G., Baars, H., Amodeo, A., Madonna, F., and Iarlori, M.: EARLINET Single Calculus Chain - technical - Part 2: Calculation of optical products, Atmos. Meas. Tech., 9, 30093029, https://doi.org/10.5194/amt-9-3009-2016, 2016.

Middleton, N. J.: Desert dust hazards: A global review, Aeolian Res., 24, 53-63, https://doi.org/10.1016/j.aeolia.2016.12.001, 2017.

Mona, L. and Marenco, F.: Volcanic Ash: Hazard Observation, Lidar Observations of Volcanic Particles, Elsevier, 161-173, 2016.

Mona, L., Amodeo, A., D’Amico, G., Giunta, A., Madonna, F., and Pappalardo, G.: Multi-wavelength Raman lidar observations of the Eyjafjallajökull volcanic cloud over Potenza, southern Italy, Atmos. Chem. Phys., 12, 2229-2244, https://doi.org/10.5194/acp-12-2229-2012, 2012.

Mona, L., Papagiannopoulos, N., Basart, S., Baldasano, J., Binietoglou, I., Cornacchia, C., and Pappalardo, G.: EARLINET dust observations vs. BSC-DREAM8b modeled profiles: 12year-long systematic comparison at Potenza, Italy, Atmos. Chem. Phys., 14, 8781-8793, https://doi.org/10.5194/acp-148781-2014, 2014.

Müller, D., Ansmann, A., Mattis, I., Tesche, M., Wandinger, U., Althausen, D., and Pisani, G.: Aerosol-type-dependent lidar ratios observed with Raman lidar, J. Geophys. Res., 112, D16202, https://doi.org/10.1029/2006JD008292, 2007.

Nicolae, D., Vasilescu, J., Talianu, C., Binietoglou, I., Nicolae, V., Andrei, S., and Antonescu, B.: A neural network aerosol-typing algorithm based on lidar data, Atmos. Chem. Phys., 18, 1451114537, https://doi.org/10.5194/acp-18-14511-2018, 2018.

Nixon, M. and Aguado, A.: Feature Extraction and Image Processing for Computer Vision, Academic Press, 632 pp., 2019.

Ortiz-Amezcua, P., Guerrero-Rascado, J. L., Granados-Muñoz, M. J., Benavent-Oltra, J. A., Böckmann, C., Samaras, S., Stachlewska, I. S., Janicka, Ł., Baars, H., Bohlmann, S., and AladosArboledas, L.: Microphysical characterization of long-range transported biomass burning particles from North America at three EARLINET stations, Atmos. Chem. Phys., 17, 5931-5946, https://doi.org/10.5194/acp-17-5931-2017, 2017.

Papagiannopoulos, N., Mona, L., Alados-Arboledas, L., Amiridis, V., Baars, H., Binietoglou, I., Bortoli, D., D’Amico, G., Giunta, A., Guerrero-Rascado, J. L., Schwarz, A., Perreira, S., Spinelli, N., Wandinger, U., Wang, X., and Pappalardo, G.: CALIPSO climatological products: evaluation and suggestions from EARLINET, Atmos. Chem. Phys., 16, 2341-2357, https://doi.org/10.5194/acp-16-2341-2016, 2016.

Papagiannopoulos, N., Mona, L., Amodeo, A., D'Amico, G., Gumà Claramunt, P., Pappalardo, G., Alados-Arboledas, L., Guerrero-Rascado, J. L., Amiridis, V., Kokkalis, P., Apituley, A., Baars, H., Schwarz, A., Wandinger, U., Binietoglou, I., Nicolae, D., Bortoli, D., Comerón, A., Rodríguez-Gómez, A., Sicard, M., Papayannis, A., and Wiegner, M.: An automatic observationbased aerosol typing method for EARLINET, Atmos. Chem. Phys., 18, 15879-15901, https://doi.org/10.5194/acp-18-158792018, 2018.

Papayannis, A., Amiridis, V., Mona, L., Tsaknakis, G., Balis, D., Bösenberg, J., Chaikovski, A., De Tomasi, F., Grigorov, I., Mattis, I., Mitev, V., Müller, D., Nickovic, S., Pérez, C., Pietruczuk, A., Pisani, G., Ravetta, F., Rizi, V., Sicard, M., Trickl, T., Wiegner, M., Gerding, M., Mamouri, R. E., D'Amico, G., and Pappalardo, G.: Systematic lidar observations of Saharan dust over Europe in the frame of EARLINET (2000-2002), J. Geophys. Res., 113, D10204, https://doi.org/10.1029/2007JD009028, 2008.

Pappalardo, G., Mona, L., D’Amico, G., Wandinger, U., Adam, M., Amodeo, A., Ansmann, A., Apituley, A., Alados Arboledas, L., Balis, D., Boselli, A., Bravo-Aranda, J. A., Chaikovsky, A., Comerón, A., Cuesta, J., De Tomasi, F., Freudenthaler, V., Gausa, M., Giannakaki, E., Giehl, H., Giunta, A., Grigorov, I., Groß, S., Haeffelin, M., Hiebsch, A., Iarlori, M., Lange, D., Linné, H., Madonna, F., Mattis, I., Mamouri, R. E., McAuliffe, M. A. P., Mitev, V., Molero, F., Navas-Guzmán, F., Nicolae, D., Papayannis, A., Perrone, M. R., Pietras, C., Pietruczuk, A., Pisani, G., Preißler, J., Pujadas, M., Rizi, V., Ruth, A. A., Schmidt, J., Schnell, F., Seifert, P., Serikov, I., Sicard, M., Simeonov, V., Spinelli, N., Stebel, K., Tesche, M., Trickl, T., Wang, X., Wagner, F., Wiegner, M., and Wilson, K. M.: Four-dimensional dis- 
tribution of the 2010 Eyjafjallajökull volcanic cloud over Europe observed by EARLINET, Atmos. Chem. Phys., 13, 4429-4450, https://doi.org/10.5194/acp-13-4429-2013, 2013.

Pappalardo, G., Amodeo, A., Apituley, A., Comerón, A., Freudenthaler, V., Linné, H., Ansmann, A., Bösenberg, J., D’Amico, G., Mattis, I., Mona, L., Wandinger, U., Amiridis, V., AladosArboledas, L., Nicolae, D., and Wiegner, M.: EARLINET: towards an advanced sustainable European aerosol lidar network, Atmos. Meas. Tech., 7, 2389-2409, https://doi.org/10.5194/amt7-2389-2014, 2014.

Pisani, G., Boselli, A., Coltelli, M., Leto, G., Pica, G., Scollo, S., Spinelli, N., and Wang, X.: Lidar depolarization measurement of fresh volcanic ash from Mt. Etna, Italy, Atmos. Environ., 62, 34-40, https://doi.org/10.1016/j.atmosenv.2012.08.015, 2012.

Ryder, C. L., Marenco, F., Brooke, J. K., Estelles, V., Cotton, R., Formenti, P., McQuaid, J. B., Price, H. C., Liu, D., Ausset, P., Rosenberg, P. D., Taylor, J. W., Choularton, T., Bower, K., Coe, H., Gallagher, M., Crosier, J., Lloyd, G., Highwood, E. J., and Murray, B. J.: Coarse-mode mineral dust size distributions, composition and optical properties from AER-D aircraft measurements over the tropical eastern Atlantic, Atmos. Chem. Phys., 18, 17225-17257, https://doi.org/10.5194/acp-18-172252018, 2018.

Sasano, Y., Browell, E. V., and Ismail, S.: Error caused by using a constant extinction/backscattering ratio in the lidar solution, Appl. Opt., 24, 3929-3932, https://doi.org/10.1364/AO.24.003929, 1985.

Sicard, M., Guerrero-Rascado, J. L., Navas-Guzmán, F., Preißler, J., Molero, F., Tomás, S., Bravo-Aranda, J. A., Comerón, A., Rocadenbosch, F., Wagner, F., Pujadas, M., and AladosArboledas, L.: Monitoring of the Eyjafjallajökull volcanic aerosol plume over the Iberian Peninsula by means of four EARLINET lidar stations, Atmos. Chem. Phys., 12, 3115-3130, https://doi.org/10.5194/acp-12-3115-2012, 2012.

Sicard, M., D’Amico, G., Comerón, A., Mona, L., AladosArboledas, L., Amodeo, A., Baars, H., Baldasano, J. M., Belegante, L., Binietoglou, I., Bravo-Aranda, J. A., Fernández, A. J., Fréville, P., García-Vizcaíno, D., Giunta, A., Granados-Muñoz, M. J., Guerrero-Rascado, J. L., Hadjimitsis, D., Haefele, A., Hervo, M., Iarlori, M., Kokkalis, P., Lange, D., Mamouri, R. E., Mattis, I., Molero, F., Montoux, N., Muñoz, A., Muñoz Porcar, C., Navas-Guzmán, F., Nicolae, D., Nisantzi, A., Papagiannopoulos, N., Papayannis, A., Pereira, S., Preißler, J., Pujadas, M., Rizi, V., Rocadenbosch, F., Sellegri, K., Simeonov, V., Tsaknakis, G., Wagner, F., and Pappalardo, G.: EARLINET: potential operationality of a research network, Atmos. Meas. Tech., 8, 4587-4613, https://doi.org/10.5194/amt-8-4587-2015, 2015.

Skamarock, W. C., Klemp, J. B., Dudhia, J., Gill, D. O., Barker, D. M., Duda, M. G., Huang, X.-Y., Wang, W., and Powers, J. G.: A Description of the Advanced Research WRF Version 3, Ncar technical note 475, National Center for Atmospheric Research, Boulder, Colorado, USA, 125 pp., 2008.

Solomos, S., Kalivitis, N., Mihalopoulos, N., Amiridis, V., Kouvarakis, G., Gkikas, A., Binietoglou, I., Tsekeri, A., Kazadzis, S., Kottas, M., Pradhan, Y., Proestakis, E., Nastos, P. T., and Marenco, F.: From Tropospheric Folding to Khamsin and Foehn Winds: How Atmospheric Dynamics Advanced a Record-Breaking Dust Episode in Crete, Atmosphere, 9, 240, https://doi.org/10.3390/atmos9070240, 2018.
Stohl, A., Forster, C., Frank, A., Seibert, P., and Wotawa, G.: Technical note: The Lagrangian particle dispersion model FLEXPART version 6.2, Atmos. Chem. Phys., 5, 2461-2474, https://doi.org/10.5194/acp-5-2461-2005, 2005.

Tesche, M., Ansmann, A., Müller, D., Althausen, D., Engelmann, R., Freudenthaler, V., and Groß, S.: Vertically resolved separation of dust and smoke over Cape Verde using multiwavelength Raman and polarization lidars during Saharan Mineral Dust Experiment 2008, J. Geophys. Res.-Atmos., 114, D13202, https://doi.org/10.1029/2009JD011862, 2009.

Tesche, M., Müller, D., Groß, S., Ansmann, A., Althausen, D., Freudenthaler, V., Weinzierl, B., Veira, A., and Petzold, A.: Optical and microphysical properties of smoke over Cape Verde inferred from multiwavelength lidar measurements, Tellus B, 63, 677-694, https://doi.org/10.1111/j.1600-0889.2011.00549.x, 2011.

Tramutoli, V.: Robust AVHRR techniques (RAT) for environmental monitoring: theory and applications, in: Earth Surface Remote Sensing II, edited by: Cecchi, G. and Zilioli, E., Vol. 3496, International Society for Optics and Photonics, SPIE, 101-113, https://doi.org/10.1117/12.332714, 1998.

Tramutoli, V.: Robust Satellite Techniques (RST) for Natural and Environmental Hazards Monitoring and Mitigation: Theory and Applications, in: 2007 International Workshop on the Analysis of Multi-temporal Remote Sensing Images, IEEE, 1-6, https://doi.org/10.1109/MULTITEMP.2007.4293057, 2007.

van der Does, M., Korte, L. F., Munday, C. I., Brummer, G.-J. A., and Stuut, J.-B. W.: Particle size traces modern Saharan dust transport and deposition across the equatorial North Atlantic, Atmos. Chem. Phys., 16, 13697-13710, https://doi.org/10.5194/acp-16-13697-2016, 2016.

Wang, Y., Sartelet, K. N., Bocquet, M., Chazette, P., Sicard, M., D’Amico, G., Léon, J. F., Alados-Arboledas, L., Amodeo, A., Augustin, P., Bach, J., Belegante, L., Binietoglou, I., Bush, X., Comerón, A., Delbarre, H., García-Vízcaino, D., GuerreroRascado, J. L., Hervo, M., Iarlori, M., Kokkalis, P., Lange, D., Molero, F., Montoux, N., Muñoz, A., Muñoz, C., Nicolae, D., Papayannis, A., Pappalardo, G., Preissler, J., Rizi, V., Rocadenbosch, F., Sellegri, K., Wagner, F., and Dulac, F.: Assimilation of lidar signals: application to aerosol forecasting in the western Mediterranean basin, Atmos. Chem. Phys., 14, 12031-12053, https://doi.org/10.5194/acp-14-12031-2014, 2014.

Wiegner, M., Gasteiger, J., Groß, S., Schnell, F., Freudenthaler, V., and Forkel, R.: Characterization of the Eyjafjallajökull ashplume: Potential of lidar remote sensing, Phys. Chem. Earth Pt. A/B/C, 45/46, 79-86, https://doi.org/10.1016/j.pce.2011.01.006, 2012.

Wilson, T. M., Stewart, C., Sword-Daniels, V., Leonard, G. S., Johnston, D. M., Cole, J. W., Wardman, J., Wilson, G., and Barnard, S. T.: Volcanic ash impacts on critical infrastructure, Phys. Chem. Earth Pt. A/B/C, 45/46, 5-23, 2012.

Zerefos, C., Nastos, P., Balis, D., Papayannis, A., Kelepertsis, A., Kannelopoulou, E., Nikolakis, D., Eleftheratos, C., Thomas, W., and Varotsos, C.: A complex study of Etna's volcanic plume from ground-based, in situ and space-borne observations, International J. Remote Sens., 27, 1855-1864, https://doi.org/10.1080/01431160500462154, 2006. 